\title{
Lithospheric structuration onshore-offshore of the Sergipe- Alagoas passive margin, NE Brazil, based on wide-angle seismic data *
}

\author{
Pinheiro Joao Marcelo ${ }^{1,{ }^{*}}$, Schnurle Philippe ${ }^{1}$, Evain Mikael ${ }^{1}$, Afilhado A. ${ }^{2}$, Gallais Flora ${ }^{1}$, \\ Klingelhoefer Frauke ${ }^{1}$, Loureiro Afonso ${ }^{3}$, Fuck R. ${ }^{4}$, Soares J. ${ }^{4}$, Cupertino J.A. ${ }^{5}$, Viana A. ${ }^{5}$, \\ Rabineau Marina ${ }^{6}$, Baltzer Agnes ${ }^{7}$, Benabdellouahed Massinissa ${ }^{6}$, Dias N. ${ }^{2,3}$, Moulin Maryline ${ }^{1}$, \\ Aslanian Daniel ${ }^{1}$, Morvan Laetitia ${ }^{8}$, Mazé Jean-Pierre ${ }^{8}$, Pierre Delphine ${ }^{8}$, Roudaut-Pitel M. ${ }^{8}$, Rio I. ${ }^{9}$, \\ Alves D. ${ }^{9}$, Barros Junior P. ${ }^{11}$, Biari Youssef ${ }^{8}$, Corela C. ${ }^{9}$, Crozon Jacques ${ }^{8}$, Duarte J.L. ${ }^{9}$, \\ Ducatel Cecile ${ }^{8}$, Falcão C. ${ }^{11}$, Fernagu Philippe ${ }^{8}$, Le Piver David ${ }^{8}$, Mokeddem Zohra ${ }^{10}$, \\ Pelleau Pascal ${ }^{8}$, Rigoti C. ${ }^{11}$, Roest Walter ${ }^{8}$, Roudaut Mickael ${ }^{8}$
}

${ }^{1}$ Institut Français de Recherche pour I'Exploitation de la MER, IFREMER, REM/GM, Centre de Brest, 29280, Plouzané, France

${ }^{2}$ Instituto Superior de Engenharia de Lisboa, ISEL, Instituto Politécnico de Lisboa, R. Conselheiro Emídio Navarro, 1959-007, Lisbon, Portugal

${ }^{3}$ Instituto Dom Luiz, Faculdade de Ciências, Universidade de Lisboa, Campo Grande, Ed. C1, Piso 1, 1749-016, Lisbon, Portugal

${ }^{4}$ Instituto de Geociências, Universidade de Brasília, Campus Darcy Ribeiro, 70910-900, Brasilia, Brazil

${ }^{5}$ Petrobras, Cenpes Research Center, Rio de Janeiro, Brazil

${ }^{6}$ Laboratoire Géosciences Océan, UMR6538, Université de Bretagne Occidentale, Place Nicolas Copernic, 29280, Plouzané, France

${ }^{7}$ Géolittomer, LETG UMR 6554-CNRS, Institut de Géographie et d'Aménagement Régional de I'Université de Nantes, Campus Tertre, BP 81227, 44312, Nantes, CEDEX 3, France

${ }^{8}$ Institut Français de Recherche pour l'Exploitation de la MER, IFREMER, REM/GM, Centre de Brest, 29280, Plouzané, France

${ }^{9}$ Instituto Dom Luiz, Faculdade de Ciências, Universidade de Lisboa, Campo Grande, Ed. C1, Piso 1, 1749-016, Lisbon, Portugal

${ }^{10}$ Laboratoire Géosciences Océan, UMR6538, Université de Bretagne Occidentale, Place Nicolas Copernic, 29280, Plouzané, France

${ }^{11}$ Géolittomer, LETG UMR 6554-CNRS, Institut de Géographie et d'Aménagement Régional de

I'Université de Nantes, Campus Tertre, BP 81227, 44312, Nantes, CEDEX 3, France

*Corresponding author : Joao Marcelo Pinheiro, email address : impgeo@gmail.com

\section{Abstract :}

The structure and nature of the crust underlying the Camamu-Almada-Jequitinhonha-Sergipe-Alagoas basins System, in the NE Brazilian margin, were investigated based on the interpretation of 12 wide- 
angle seismic profiles acquired during the SALSA (Sergipe ALagoas Seismic Acquisition) experiment in 2014. In this work, we present two 220-km-long NW-SE combined wide-angle and reflection seismic profiles, SL 01 and SL 02, that have been acquired using 15 ocean-bottom-seismometers along each profile, offshore the southern part of the Sergipe Alagoas Basin (SAB), north of the Vaza-Barris Transfer zone. The SL 02 has a 150-km long inland continuation with 20 land-seismic-stations until the Sergipano Fold Belt (SFB). Wide-angle seismic forward modeling allows us to precisely divide the crust in three domains: beneath the continental shelf, a $\sim 100 \mathrm{~km}$ wide necking zone is imaged where the continental crust thins from $\sim 35 \mathrm{~km}$ on the Unthinned Continental Domain, which displays a threelayered crust structure, to less than $8 \mathrm{~km}$ on the Oceanic Crust Domain. In the necking zone, the upper and the middle layers thin dramatically and almost disappear, while the Moho discontinuity shows clear PmPs. The Continental-Oceanic Crust Boundary (COB) is located at $\sim 80 \mathrm{~km}$ from the coastline and is marked by intracrustal seismic reflectors and changes in the seismic velocity, showing a sharp transition. On profile SL02, the oceanic crust is perturbed by a volcanic edifice together with an anomalous velocity zone underneath the area.

\section{Highlights}

Sergipe Alagoas Basin passive margin modeling. Wide-angle refraction seismic integrated with Multi-Channel reflection seismic data. Location of the Continental- Oceanic crust boundary. Lithospheric structuration and segmentation of Brazil's margin in Central Atlantic.

Keywords : South Atlantic Ocean, NE Brazil, Sergipe-Alagoas Basin, Passive Margins, Wide-angle refraction seismics, Crustal structure, Tectonic Inheritance.

We would like to thank two anonymous reviewers and the editor Dr. F. Audemard, who helped to improve significantly this manuscript. 
41 Introduction

42 Understanding the processes that led to the breakup of West Gondwana (Figure 1A) and the

43 formation of the south Atlantic Margins are still not fully achieved. The North - East Brazilian

44 margins, which are very segmented margins, in various structural and inheritance contexts, where

45 the aborted Recôncavo - Tucano - Jatoba rift system connects with the NS Jequitinhonha -

46 Camamu-Almada and NE-SW Jacuípe - Sergipe-Alagoas rift systems are a strategic area to study

47 the influence of the tectonic inheritance on margin's formation. The connection between the three

48 system forms the Camamu triple junction. The SALSA experiment, conducted in 2014 by the

49 Department of Marine Geosciences (IFREMER: Institut Français de Recherche pour l'Exploitation

50 de la MER, France) and PETROBRAS (Brazil), in collaboration with the Laboratory of Oceanic

51 Domain (IUEM: Institut Universitaire et Européen de la Mer, France), the Faculdade de Ciências da

52 Universidade de Lisboa (IDL, Portugal) and the Universidade de Brasilia (Brazil), is aimed at constraining the crustal structure, the segmentation and the geodynamical setting of the

54 Jequitinhonha-Almada-Camamu-Jacuípe-Alagoas-Sergipe margin segments.

55 In the year 2000's high quality seismic profiles from ION-GXT were acquired off Brazil's coast, and a few of these profiles have been published, particularly in the Brazilian southeastern margin (e.g., Henry et al., 2009; Kumar et al., 2012). The location of the SALSA profiles follows the location of some of the ION-GXT profiles. Seismic shots, Multi-Channel Seismic (MCS) acquisition and Ocean Bottom Seismometers (OBS) deployments were performed by the French R/V L'Atalante (IFREMER) along twelve profiles (Figure 1B). Among them, five were extended onshore by Land Seismic Stations (LSS). Here, we present the results on P-wave velocity models, based on the combined interpretation of multi-channel and wide-angle seismic data, of two profiles imaging the Sergipe-Alagoas basin ( $\mathrm{SAB})$, located in the northern part of the experiment, north to the Vaza-Barris transfer zone (Figures 1C and 2). The remaining basins studied during the SALSA project (Camamu (Loureiro et al., 2018), Jacuípe, Tucano and Sergipe-Alagoas basins) will be discussed in companion papers. 

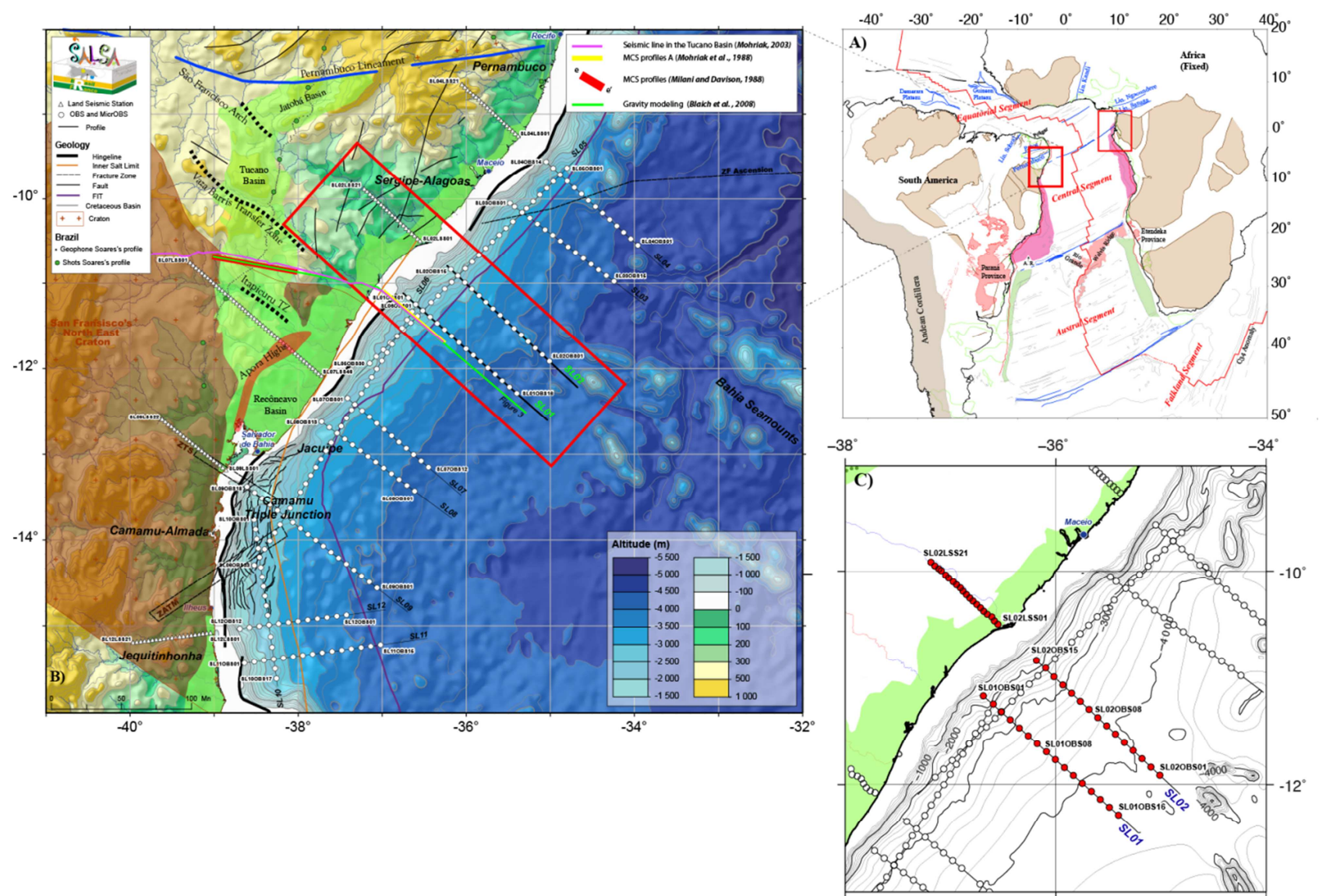

Figure 1: Location of profiles of the SALSA experiment: A) General reconstruction map at Chron C34 of studied area and conjugate margin (Moulin et al., 2010). B) Bathymetry and topography on land (IHO-IOC GEBCO, 2014). Ocean Bottom Seismometers (OBSs) are marked by white dots, MCS profiles by thick black lines, land-stations by white triangles. The SLO1 and SLO2 profiles are highlighted by red rectangle. The color lines represent the location of profiles already published in this area. Dashed black line denotes main transfer zones (Blaich et al., 2008). Green area indicates the Recôncavo-Tucano-Jatoba (RTJ) basins (Bizzi et al., 2003). Brown area indicates the limits of the Sao Francisco Craton, adapted from Hasui (2012). TMAZ: Taipus-Mirim Accommodation Zone. Note that Bahia Seamounts are characterized by an elongated NW-SE direction. C) Bathymetry (IHO-IOC GEBCO, 2014) around the profiles discussed in the present paper.

\section{Geological Setting}

Whilst in Albian time the central part of the South Atlantic presented the first oceanic crust, the Equatorial Atlantic Ocean was only starting to open, as the last stage of the breakup of the Atlantic Ocean, allowing the definitive water connection between the Central Atlantic and the South Atlantic oceans (Moulin et al., 2010). From the Potiguar Basin to the north to the Camamu triple junction to the south (figure 1A), this area represents a buffer zone between these two different geodynamical settings (Conceiçao and Zalan, 1998; Moulin et al., 2010).

This buffer zone is characterized by a SW-NE elongated margin, oblique respect to the main direction of the Fracture zones of the central segment of the South Atlantic Ocean. Onshore the presence of a failed N-S and E-W rift: the Recôncavo-Tucano-Jatoba rift, marks the limit of the Triangle-shaped Tucano Microplate, which rotated counterclockwise (Szatmari et al., 1999; Moulin et al., 2010) during the South Atlantic opening. The Sergipe Alagoas Basin (SAB) is situated in the 
middle of the eastern branch of this triangle, to the north of the Vaza-Barris Fault, which marks the

91 boundary between the Sergipe basin and Jacuipe basin depocenters. It is in the east of the Sergipano Fold Belt (SFB) and south of the Pernambuco lineament, which are geological structures associated with the tectonic development of NE Brazil (Figure 2), inherited from the Neoproterozoic Brasiliano Orogeny (Davison et al., 1995). The role of the Vaza-Barris transfer zone, is not yet completely understood, but it plays a significant role in the actual framework of the Brazilian margin, as it divides the Tucano basin and produces a flip in the location of its depocenters. Stratigraphically, the SAB is one of the few basins that presents Paleozoic to Jurassic/Early Cretaceous pre-rift sequences related to intracratonic subsidence and is the northern limit of the evaporite deposits (Cainelli and Mohriak, 1998).

100

Sediments in the SAB lie over the Proterozoic SFB (Figure 2). The SFB is located between the Pernambuco-Alagoas Massif and the São Francisco Craton (SFC) (Figures 1 and 2) with a triangular shape narrowing towards the west (Figure 2). The geological history of the SFB has been the subject of numerous studies (e.g. Almeida et al., 1977; Davison and Santos, 1989; D'el-Rey Silva, 1999). Recently Oliveira et al. (2010), based on U-Pb SHRIMP (Sensitive High-Resolution Ion Microprobe) and detrital zircons ages from Carvalho et al. (2005), proposed that the evolution of the Sergipano Belt began with the breakup of a Palaeoproterozoic continent followed by development of a Mesoproterozoic ( $\approx 980-960 \mathrm{Ma}$ ) continental arc possibly on the margin of the Palaeoproterozoic Pernambuco-Alagoas Massif. The extension of this continental block resulted in a stretched margin, a passive margin on the southern edge of the Pernambuco-Alagoas Massif with a rift in between. A second passive margin was formed on the São Francisco Craton. Convergence

111 of the Pernambuco-Alagoas Massif and the São Francisco Craton led to deformation in shelf 112 sediments, build-up of a continental arc between $630 \mathrm{Ma}$ and $620 \mathrm{Ma}$, and subsequent exhumation 113 and erosion of the Pernambuco-Alagoas Block, led to deposition of the uppermost Pre-Cambrian 114 clastic sediments (Oliveira et al., 2010).

115 The SAB presents a complete rift stratigraphic record (Mohriak, 2003). The initial rift deposits 116 records can be observed in the onshore part of the SAB. Gomes (2005), using well logs information 117 with seismic data (Cainelli, 1992), had tracked continuous seismic horizons related to the base of 118 the Calumbi Formation, which marks the beginning of the drift phase. Campos Neto et al. (2007) 119 elaborated the Petrobras stratigraphic chart, following the lithostratigraphic classification proposed by Schaller (1970) and Feijó (1994).

121 Mohriak et al. (1995, 1998, 2000) and Mohriak (2003) interpreted the regional seismic section 238122 RL-343 (Figures 1 and 3). This profile is perpendicular to the coast and hinge line and extends for 123 about $110 \mathrm{~km}$ from the platform to the deep water-region of the SAB. He did an interpretation 
stratigraphically calibrated by exploration boreholes and structurally constrained by gravity modelling. The results of a deep geoseismic transect were also used by Blaich et al. $(2008,2011)$ to model the crust of the SAB in combination of new gravity data. From these past studies, we can assume some key elements:

Mohriak et al. (1998) described a conspicuous array of strong undulated reflectors in the lower portion of the profile (Figure 3) forming an anticlinal structure that rises from the westernmost portion of the profile until the apex near the shelf-break and extends as a band of reflectors throughout most of the profile (Figure 3), from slope to deep basin. He suggested that they might correspond to intracrustal horizons that probably mark the transition from the lower crust to the upper mantle ultramafic rocks (Kemplerer et al., 1986).

Mohriak et al. (1998) observed some structures in the proximal deep-water basin that was interpreted as igneous bodies (Figure 3). One example is a plug interpreted as a post-rift volcanic intrusion close to the Continental Ocean Boundary (COB) (Figure 3). Bordering this plug, in the proximal side, there are packages of reflectors with a sigmoidal geometry, mostly dipping seawards, but also dipping landwards, that probably correspond to seaward-dipping-reflectors and landward dipping reflectors (SDRs and LDRs) (Figure 3), which were interpreted as formed by volcanic rocks extruded during early phases of spreading oceanic ridges (Mohriak et al., 1998). These magmatic features are usually associated with extensional processes and oceanic crust inception, and therefore post-date the rift-phase lithospheric extension associated with the break-up of Gondwana in the Early Cretaceous. On the base of this observations, Mohriak et al. (1995) suggested that the central segment of the South Atlantic African margins could also be considered as a volcanic margin such as the Norwegian margin (e.g. Eldholm et al., 1989), the Greenland margin (e. g. Korenaga et al., 2000), the Aden margin (Tard et al., 1991) or the Namibia margin (Bauer et al., 2000; Austin and Uchupi, 1982). However, Moulin et al. (2005) have quoted the differences between the $4 \mathrm{~km}$ thick SDRs layer lying on top of a $30 \mathrm{~km}$-thick igneous crust and extending over a lateral distance of $150 \mathrm{~km}$ on the Greenland margin (Korenaga et al., 2000) and this less than $20 \mathrm{~km}$ wide and less than $3 \mathrm{~km}$ thick SDRs described by Mohriak et al. (1995). They argued that if their thickness is similar, their lateral extensions are quite different and the same genetic process can hardly be attributed to both structures.

- Assuming a simple geologic model based in thinning of the crust with mantle rising from 35 $\mathrm{km}$ in the onshore region to about $25 \mathrm{~km}$ at the platform, and to about $20 \mathrm{~km}$ near the shelf edge, the gravity modelling for the Sergipe sub-basin and the Jacuipe Basin suggests a very rapid crustal thinning near the present-day shelf edge (Mohriak et al., 1995, 1998). According to this modelling, the Moho topography gets more regular from slope to seawards with depths between 15 and $18 \mathrm{~km}$ across the COB (Figure 3). 
TPIV INASCRIPT modeling of Blaich et al. (2008) required the introduction of a lower crustal high-density body in

161 the proximal part of the gravimetric profile, in the necking zone, between $200 \mathrm{~km}$ and $300 \mathrm{~km}$

162 distance (Figure 4). For these authors this high-density body would indicate a volcanic margin 163 character.

164 - The COB location was evaluated by this 2D gravity modelling (Blaich et al., 2008) and 165 illustrates also a Moho discontinuity that shallows very rapidly eastward of the depocenter, rising from $33 \mathrm{~km}$ to $18 \mathrm{~km}$ depth within a distance of about $70 \mathrm{~km}$, not so different of the model proposed by Mohriak et al. (1998).

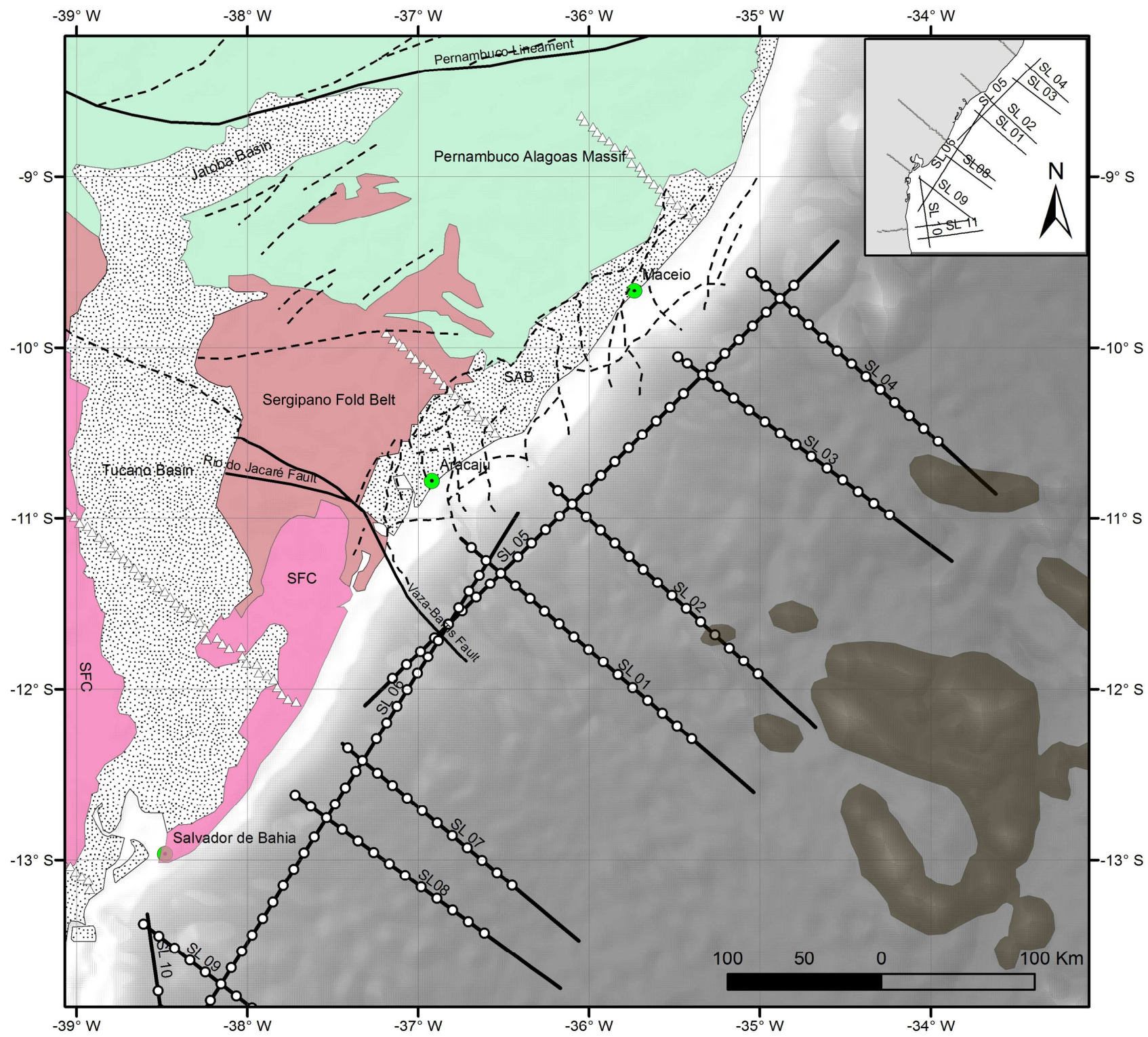

\section{Legend}

Land Seismic Stations (LSS)

Ocean Bottom

- Seismometer (OBS)

- Salsa profiles

\section{Structures}

-... Fractures and faults

Principal lineaments and zones of transference
Geology

Cretaceous basins

Proterozoic orogenic belts Palaeoproterozoic Borborema Province

Palaeoproterozoic

São Francisco Craton

Bahia Seamounts 
170 Figure 2. Geological Map of the Basin Sergipe-Alagoas and region around (modified from Lana, 1990,) with the SALSA profiles, the principal faults and fractures, and the geological features associated with the São Francisco

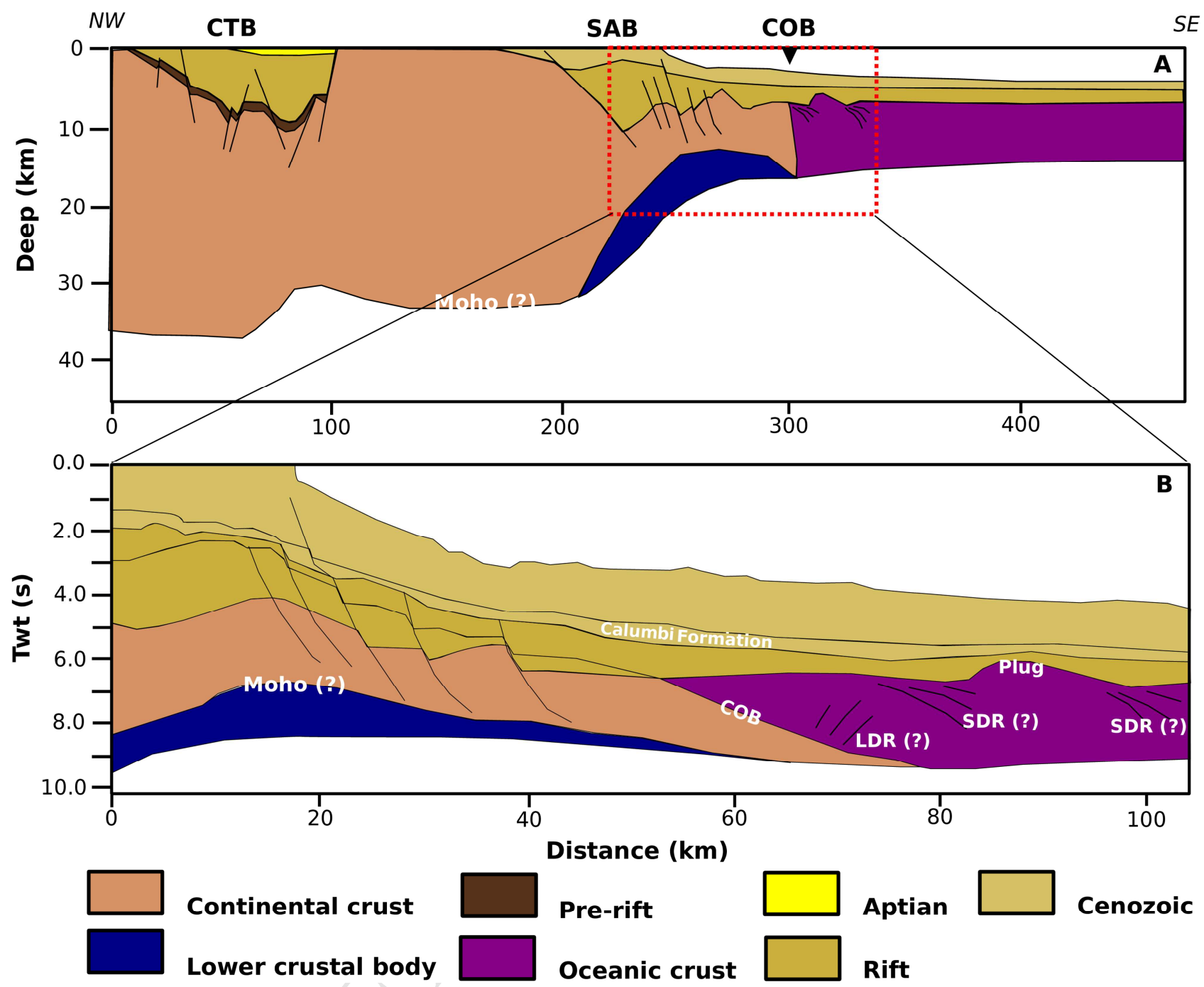

Figure 3: a) Gravity modelled transect in SAB modified from Blaich et al. (2008), represented by the blue line in figure 1. The red dotted square in the gravity model represents the location of the seismic profile 239-RL-343, the area inside the square was modelled based on seismic data and the rest on gravity data; b) Interpreted deep seismic profile 239RL-343 by Mohriak et al. (1995, 1998, 2000), represented by the red line in figure 1. CTB, Central Tucano Basin; SAB, Sergipe Alagoas Basin; COB Continental-Oceanic Boundary; SDR, Seaward Dipping Reflectors; LDR, Landward Dipping Reflectors.

\section{Data Processing and Modeling}

181 The ION-GXT profiles are high quality reflection seismic profiles. However, the time-to-depth

182 inversion made to transform the time data into depth data are not based on high-accuracy crustal P183 wave velocities. The SALSA refraction seismic profiles were located following some ION-GXT 184 profiles positions, allowing in the future an integration of more detailed crustal P-wave velocities 
obtained by wide-angle refraction data. During the SALSA experiment, Multi-Channel Seismic (MCS) acquired jointly with refraction data was processed using the Geocluster (CGG Veritas) software. The processing sequence was composed of geometry, wave-equation multiple attenuation, shot-gather predictive deconvolution, time variant band-pass filter, random multiple attenuation, normal move-out, CMP stack and post-stack FK time migration. A last step of seismic data processing is the pre-stack depth migration of the MCS data using the results of wide-angle seismic data modeling, followed by residual move-out analysis. This procedure uses both near-vertical and wide-angle seismic data sets to produce a depth seismic section, which images both the sedimentary crust as well as the basement. Furthermore, it allows to verify the accuracy of the wide-angle velocity model in the sedimentary sequences.

\section{Results}

197 Despite the profiles SL01 and SL02 being parallel, $75 \mathrm{~km}$ apart, and in the same sedimentary basin, each multi-channel seismic image shows a very different sedimentary stratigraphy and basement geometry (Figure 4). While the southern SL01 MCS record-section shows some chaotic patterns, with heterogeneous layers, sometimes truncations, and a basement with a quite irregular topography, the SL02 MCS record-section, shows some plan-parallel layers (except the seafloor, that is quite irregular in the proximal part). Sometimes, there are some completely seismically transparent areas, which might be associated with erosional boundaries (Figure 4).

SL01

The SL01 line is a $210 \mathrm{~km}$ long and NW-SE oriented profile that spans from the continental slope to the distal basin. It is coincident with the ION-GXT 2275 profile and parallel to the associated SL02 profile; both refraction profiles were planned to study the crustal architecture of the SAB (Figure 1). At sea, a total of 16 OBS (instruments with four components: Hydrophone plus 3-Comp. Seismometer) were deployed, spaced every $13 \mathrm{~km}$, at water depths of $1560 \mathrm{~m}$ to $4320 \mathrm{~m}$. The 1376 air-gun shots in SL01 were recorded by all instruments. The quality of the recorded signal is very

211 good. This profile crosses two margin parallel profiles designed to image the segmentation (Evain 212 et al., in prep.): the SL06 profile at the SL01OBS02 and the SL05 profile at the SL01OBS03 in the 213 proximal part.

214 In the OBS data, several near-offset reflected and associated refracted arrivals are visible, 215 decreasing in number as we move towards the distal basin. 
From SL01OBS01 onward, the full subsurface sedimentary, crustal, and mantellic sequence is

217 imaged from shots at the vertical of each OBS to offsets reaching $110 \mathrm{~km}$. In addition to clear Pg1,

$218 \mathrm{Pg} 2, \mathrm{Pg} 3, \mathrm{Pu}, \mathrm{Pn}$ (mostly) first arrivals (represented with blue, violet and magenta shades), Ps1 to

219 Ps6 sedimentary refracted arrivals, traveling with apparent velocity increasing from less than $2 \mathrm{~km} / \mathrm{s}$

220 (close to the water-cone) up to $3 \mathrm{~km} / \mathrm{s}$, are observed as secondary arrivals (represented with red,

221 orange, yellow, and light-green shades). The shallowest layer, is very slow $(1.85 \mathrm{~km} / \mathrm{s})$ and not very

222 well marked on the seismic profile, but is necessary to fit correctly the secondary later arrivals.

223 From the second to fifth layer, the velocity increases from $2.00 \mathrm{~km} / \mathrm{s}$ to $3.10 \mathrm{~km} / \mathrm{s}$. From

224 SL01OBS01 to SL01OBS03, these layers do not show evidence of clear refracted arrivals and were

225 positioned according to the reflected arrivals. The Ps6 refraction shows top and bottom velocities

226 from $3.35 \mathrm{~km} / \mathrm{s}$ to $3.45 \mathrm{~km} / \mathrm{s}$. Furthermore, at near-critical incidence, high-amplitude reflections are

227 observed, particularly from the tops of the lower crust Pg3P, Unknown unit PuP, and Moho PmP on

228 the seaward-side of OBSs. The Pg1 phase presents the shortest offset span (from $\sim 7.5$ to $20 \mathrm{~km}$

229 offset, as we can see in the SL01OBS03 (Figure 5); and the largest curvature indicative of larger

230 velocity gradient. The Pg2 extends from 20 to $\sim 50 \mathrm{~km}$ offset and Pg3 from 50 to $\sim 80 \mathrm{~km}$ offset and

231 present the lowest apparent velocity gradient.

232 In the distal oceanic part, from 90 to $220 \mathrm{~km}$ model distance, from SL01OBS08 (Figure 6) to

233 SL01OBS15 (Figure 7), the data shows only four sedimentary layers and the related phases, Ps1 to

234 Ps4 remain weak, and almost indistinguishable refracted arrival phases that are recorded as a fan of 235 second arrival phases with slightly increasing velocities and relatively low velocity-gradients that 236 emerges from the water cone. These phases were also modelled according to the reflected arrivals.. 237 In the presumed oceanic basin, the $\mathrm{Pg} 1, \operatorname{Pg} 2$ and $\mathrm{Pg} 3$ refracted phases form a relatively continuous 238 event in both amplitude and apparent velocity, without sharp inflections indicative of major velocity 239 changes between layers. The PuP phase spans from 0 to $80 \mathrm{~km}$ model distance with apparent 240 velocity close to $\mathrm{Pg} 3$ in the necking zone. Pn is observed emerging at $\sim 70 \mathrm{~km}$ offset with an 241 apparent velocity increasing from 7.90 to more than $8.10 \mathrm{~km} / \mathrm{s}$ and large amplitude variations both 242 along offset and OBSs. 

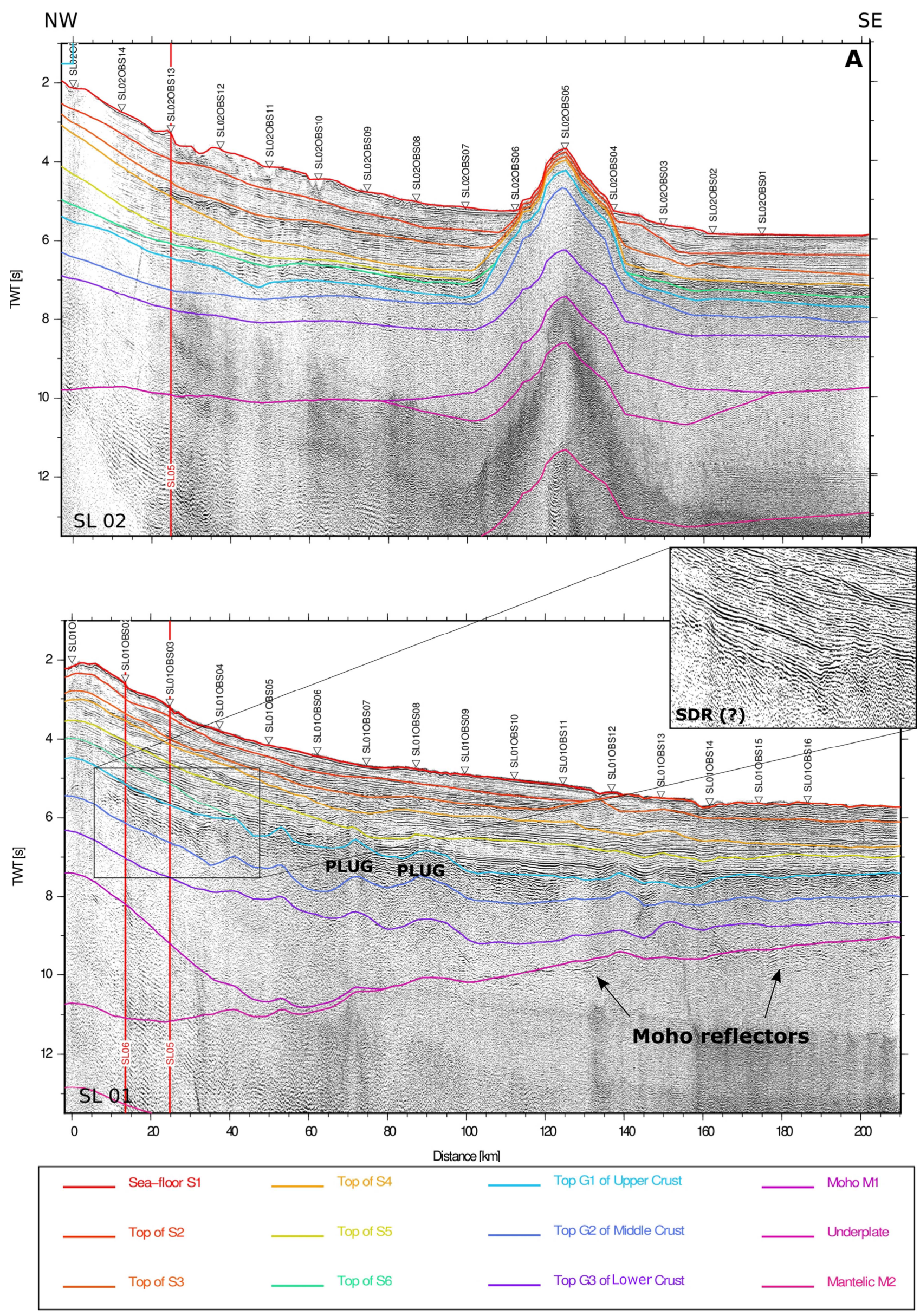
Figure 4: Two-way travel-time record section of MCS data along SL02 (A) and SL01 (B) profiles overlain by time converted interfaces of wide-angle model. The intersections with the SALSA dataset are indicated by red line. OBS locations are indicated by white triangle. Vertical exaggeration at seafloor is $1: 12.5$

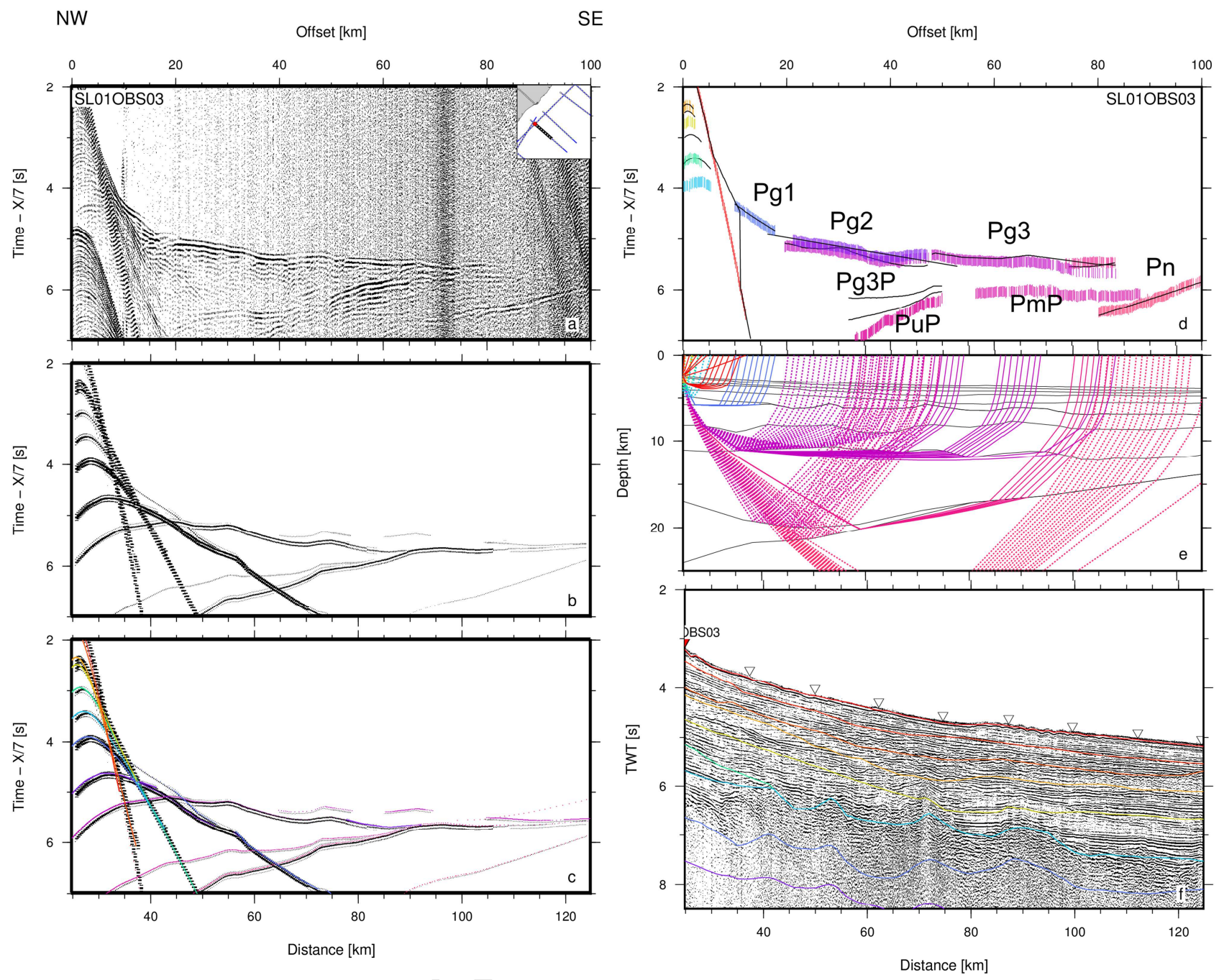

Figure 5: SLO1OBSO3 on profile SL01 on the SAB. a) Seismic record; b) Synthetics; c) Color coded synthetic; d) Color coded observed travel-times overlain by predicted times in black; e) Seismic rays; f) MCS time migrated section and color-coded model interfaces. On a, b, c, and d, travel-time is reduced by a velocity of $7 \mathrm{~km} / \mathrm{s}$.

\section{Velocity model}

256 From SL01 wide-angle data, we digitized 25741 events and interpreted their respective phases. Travel-time uncertainty was estimated on the SL01OBS records and fixed at $0.030 \mathrm{~s}$ for the water, $2580.050 \mathrm{~s}$ for the sedimentary arrivals increasing to $0.100 \mathrm{~s}$ for the crustal and mantellic arrivals. The 259 model explains the travel-time and phase of 21204 events or $82 \%$ of total picks, with a global RMS travel-time residual of 0.119 s. Given our events individual uncertainty, the model results in a normalized chi-squared of 1.406. Generally, the SL01 model correctly explained the SL01OBS with chi-squared and rms acceptable values (Table 1).

263 The final velocity model of profile SL01 images all the sedimentary and basement layers to a depth of around $25 \mathrm{~km}$ (Figure 8B). 
The model has a sedimentary cover with 6 sedimentary layers in the continental part and 4 layers in the presumed oceanic basin, that reach a thickness of $5 \mathrm{~km}$ for all along the profile. $\mathrm{S} 1 \mathrm{has}$ no lateral velocity gradient with top and bottom seismic velocities of $1.75 \mathrm{~km} / \mathrm{s}$ to $1.80 \mathrm{~km} / \mathrm{s}$. S2 has a lateral gradient in the velocities that goes from $2.00 \mathrm{~km} / \mathrm{s}$ in the western part of the profile and gradually decreases up to $1.80 \mathrm{~km} / \mathrm{s}$. The two first sedimentary layers pinch out at $130 \mathrm{~km}$ in the distal basin.

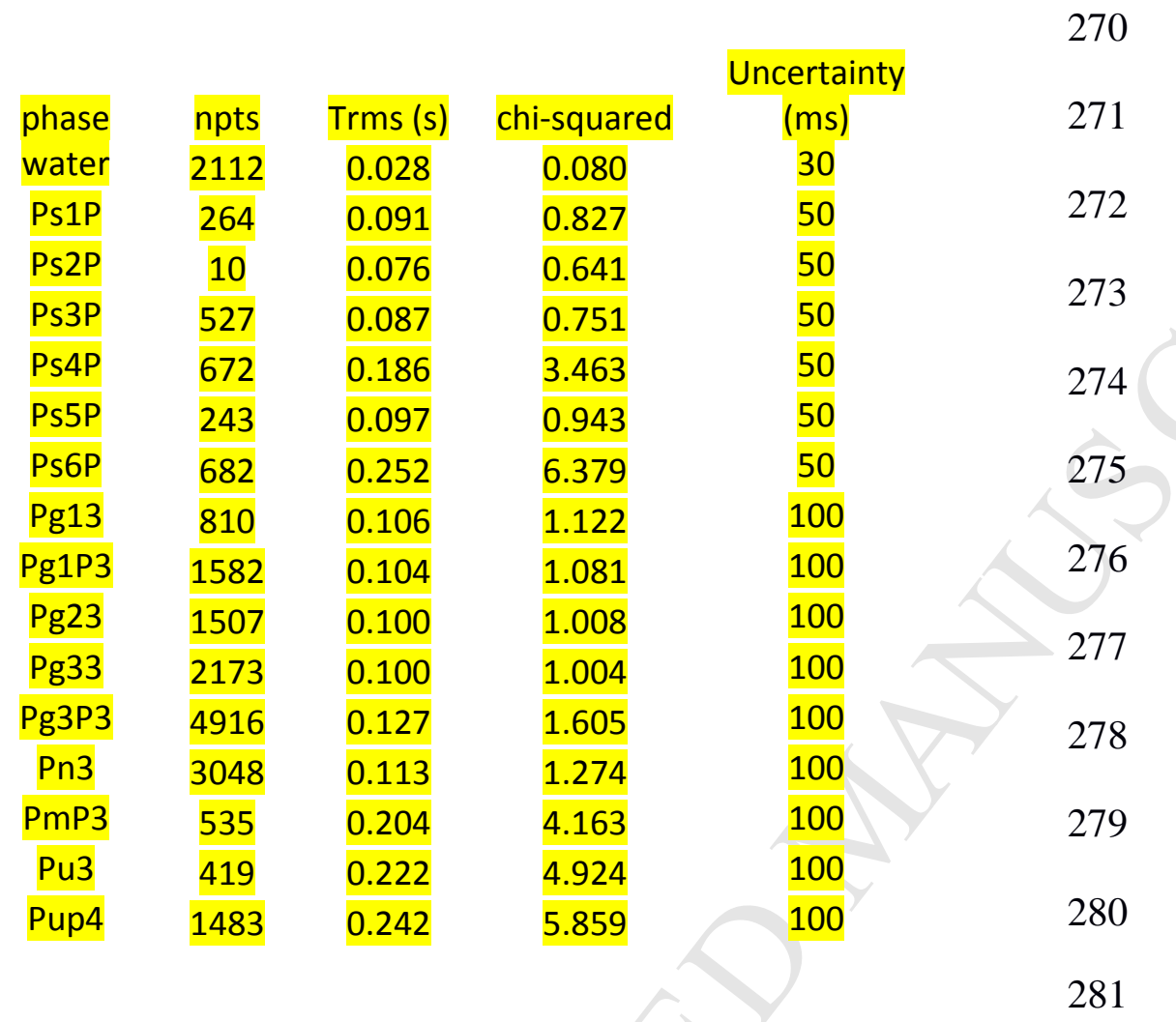

282

Table 1: Reflected or refracted phase name, number of explained events, residual mean-square, and normalized chisquared value for the SLO1 model.

$\mathrm{S} 3$ has top and bottom velocities from $2.40 \mathrm{~km} / \mathrm{s}$ to $2.50 \mathrm{~km} / \mathrm{s}$. S4 has regular top and bottom velocities from $2.85 \mathrm{~km} / \mathrm{s}$ to $3.00 \mathrm{~km} / \mathrm{s}$. S5 has also regular top and bottom velocities from 3.10 $\mathrm{km} / \mathrm{s}$ to $3.15 \mathrm{~km} / \mathrm{s}$ on the distal basin and a constant velocity of $2.95 \mathrm{~km} / \mathrm{s}$ on the continental slope. S6 appears only in the continental slope zone, over a basement depression, and pinches out at $40 \mathrm{~km}$ and has top and bottom velocities from $3.35 \mathrm{~km} / \mathrm{s}$ to $3.45 \mathrm{~km} / \mathrm{s}$.

The lithospheric structure has five layers: upper crust, middle crust, lower crust, anomalous velocity zone and lithospheric mantle. The upper crust has a thickness of $2.5 \mathrm{~km}$ on the continental slope and decreases to $1.0 \mathrm{~km}$ and $1.5 \mathrm{~km}$ on the distal basin with a very irregular topography, full of basins and mounts, with velocities at the top and bottom of $5.00 \mathrm{~km} / \mathrm{s}$ and $5.10 \mathrm{~km} / \mathrm{s}$, a little decrease to $4.85 \mathrm{~km} / \mathrm{s}$ at $110 \mathrm{~km}$ and increases to $5.10 \mathrm{~km} / \mathrm{s}$ and $5.20 \mathrm{~km} / \mathrm{s}$ at the distal basin. The middle crust has regular thickness of $2.5 \mathrm{~km}$ for all along the profile, with velocities at the top and bottom from $6.50 \mathrm{~km} / \mathrm{s}$ to $6.60 \mathrm{~km} / \mathrm{s}$. The lower crust starts with a thickness of $5 \mathrm{~km}$ in the very northwestern 
part of the profile, and thickens to $10 \mathrm{~km}$ between 20 and $70 \mathrm{~km}$ and thins to $3.0 \mathrm{~km}$ towards the ocean, with velocities at the top and bottom from $7.00 \mathrm{~km} / \mathrm{s}$ to $7.20 \mathrm{~km} / \mathrm{s}$.

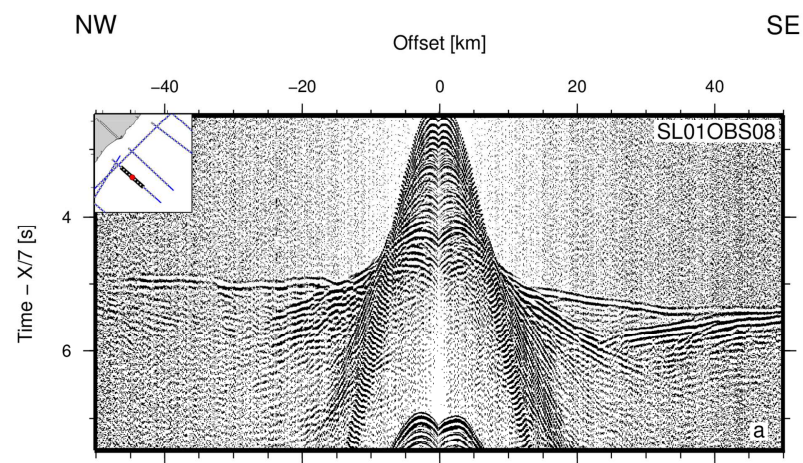

SE

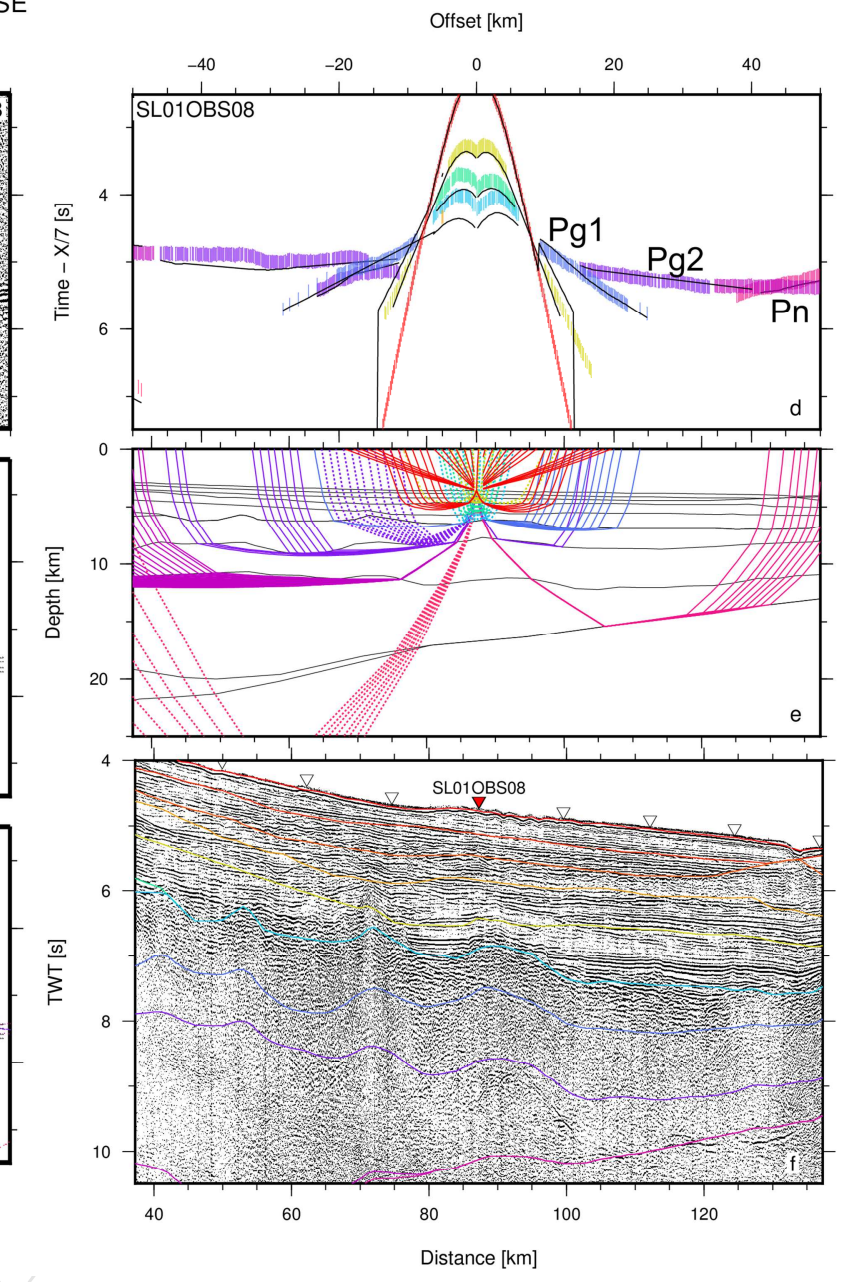

Figure 6: SL01OBSO8 on profile SL01 on the SAB. a) Seismic record; b) Synthetics; c) Color coded synthetic; d) Color coded observed travel-times overlain by predicted times in black; e) Seismic rays; f) MCS time migrated section and color-coded model interfaces. On $a, b$, c, and d, travel-time is reduced by a velocity of $7 \mathrm{~km} / \mathrm{s}$.

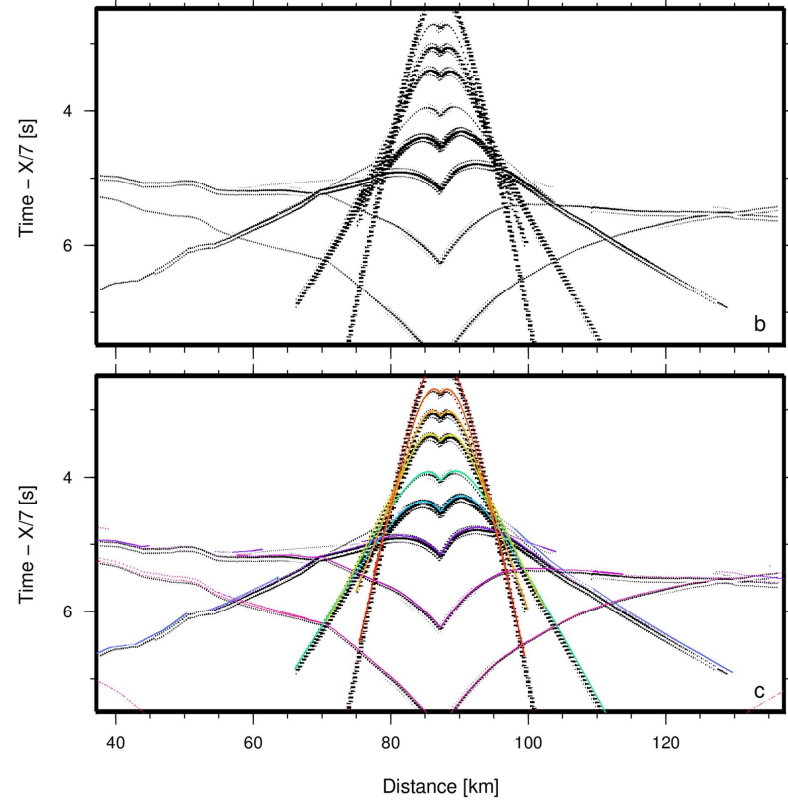



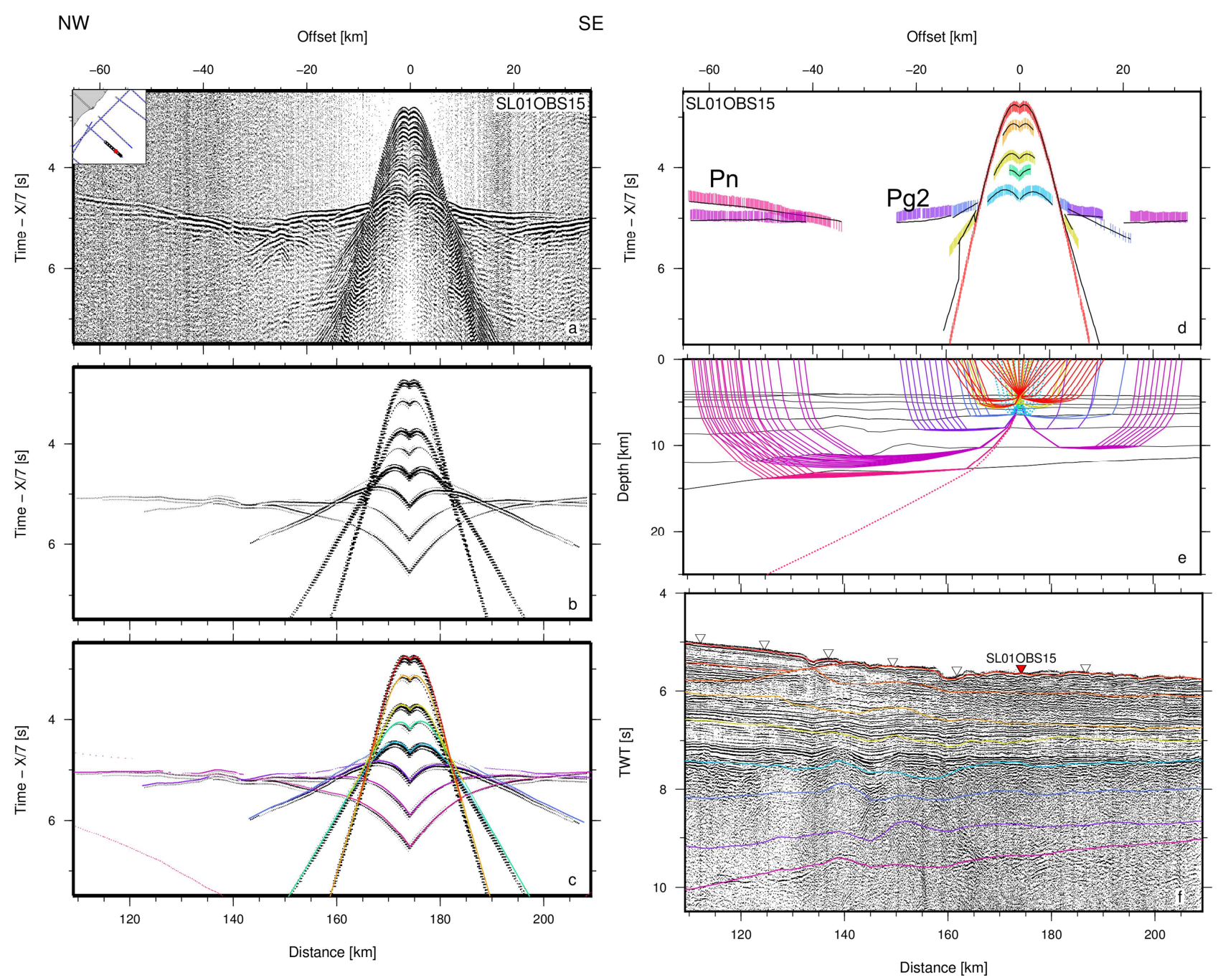

313 Figure 7: SLO1OBS15 on profile SLO1 on the SAB. a) Seismic record; b) Synthetics; c) Color coded synthetics; d)

314 Color-coded observed synthetic; d) Color coded observed travel-times overlain by predicted times in black; e) Seismic 315 rays; f) MCS time migrated section and color-coded model interfaces. On $a, b, c$, and $d$, travel-time is reduced by a 316 velocity of $7 \mathrm{~km} / \mathrm{s}$.

317 The anomalous velocity zone, located at the necking zone, is badly constrained, showing its 318 possible reflected arrival only in the two most proximal OBSs. These reflected arrivals can also be 319 the result of an internal reflector, representing some intra-crustal body. With this information and 320 the ION-GXT data (Figure 8B), this zone was modeled with $10 \mathrm{~km}$ thickness, that thins abruptly 321 until pinching out against the lower crust at $80 \mathrm{~km}$. This zone presents velocities between the top 322 and the bottom from $7.20 \mathrm{~km} / \mathrm{s}$ to $7.25 \mathrm{~km} / \mathrm{s}$. The top of the lithospheric mantle below the Moho has 323 a velocity of $7.90 \mathrm{~km} / \mathrm{s}$. Note that an additional lithospheric layer located at 10 to $15 \mathrm{~km}$ below the 324 Moho, with $8.10 \mathrm{~km} / \mathrm{s}$, is necessary to provide a gradient capable of explaining the Pn arrivals. It is 
well constrained in the proximal part of the two profiles, but only in the distal part of SL02 profile 326 (Figure 8A).

SL02

329 The SL02 line is a $220 \mathrm{~km}$ long and NW-SE oriented profile, parallel to SL01, that spans offshore 330 from the continental platform to the distal basin. The SL02 was extended inland along a distance of $331150 \mathrm{~km}$ from the most proximal OBS, for a total profile length of $370 \mathrm{~km}$. It is coincident with the 332 ION-GXT 2300 profile (Figure 8A).

333 At sea, a total of 15 OBS (instruments with four components: Hydrophone plus 3-Comp. 334 Seismometer) were deployed, spaced every $13 \mathrm{~km}$, at water depths of 1.557 to $4.368 \mathrm{~m}$ (Figure 1C). 335 The 1271 air-gun shots in SL02 were recorded by all instruments. The quality of the recorded signal 336 is very good. Inland, the profile was extended $150 \mathrm{~km}$ towards the North-West with the deployment 337 of 21 Land Seismic Stations (LSS, spaced every $5 \mathrm{~km}$ ). The profile has $100 \mathrm{~km}$ of extension 338 because, unfortunately, there is a gap of about $50 \mathrm{~km}$ between the last LSS and the first OBS, on the 339 inner shelf. This profile crosses the SL05 profile at the position of the SL02OBS02 and 340 SL05OBS14, in proximal position.

341 The geometry of the sedimentary and crustal layers onland beneath the seismic land stations can 342 further be constrained from geological and geophysical studies conducted in the study area (Chang 343 et al., 1992; Soares et al., 2010; Tavares et al., 2012; de Lima et al., 2015). Surface geology 344 indicates the Sergipano Fold Belt from SL02LSS11 to SL02LSS01, and an outcrop of Quaternary 345 deposits from SL02LSS21 to SL02LSS10, as shown at the SL02LSS15 (Figure 9). 


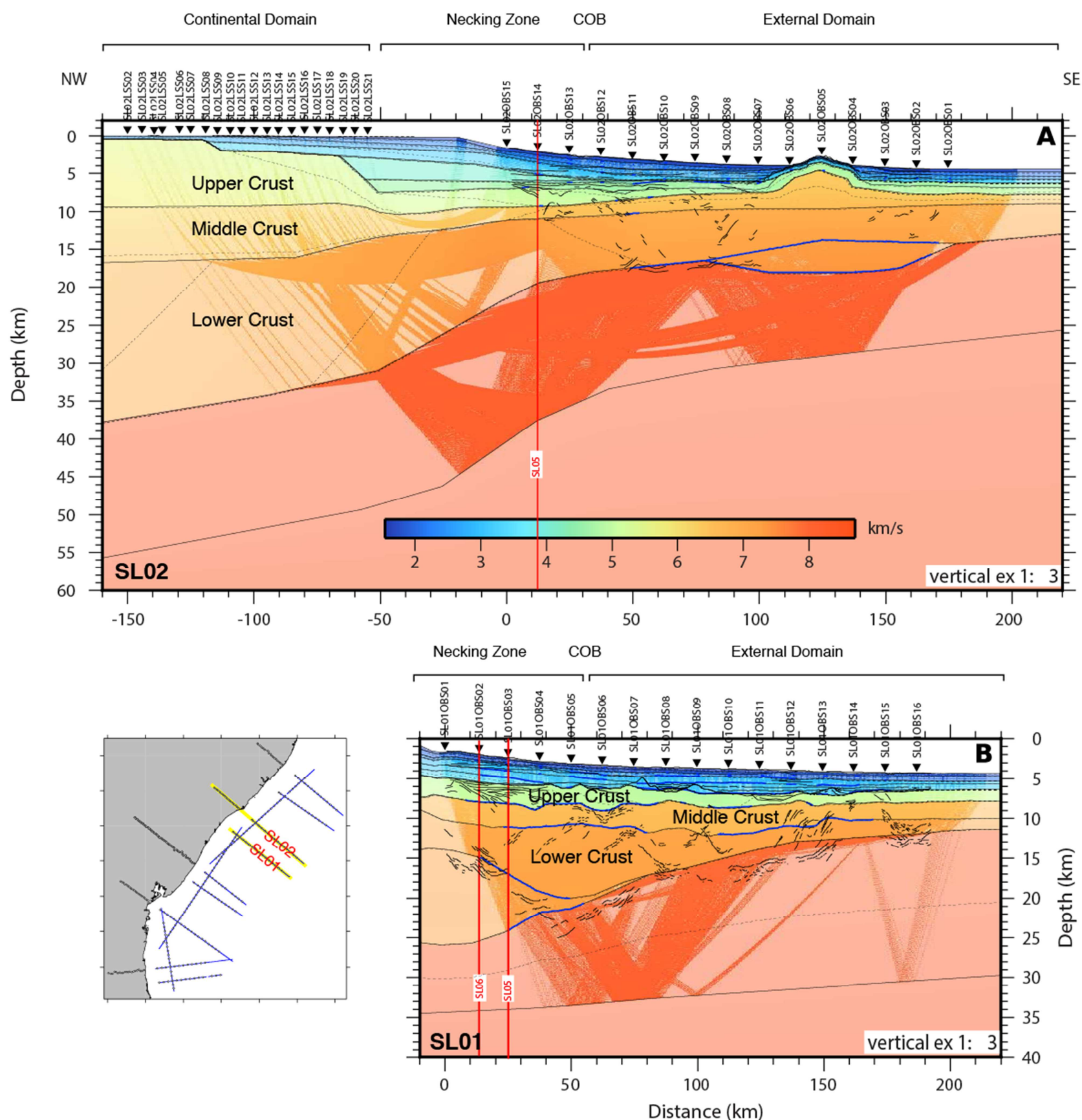

Figure 8: Final P-wave interval velocity models along SLO2 (A) and SLO1 (B) profiles overlaid by the respective linedrawing of the ION-GXT lines. Black lines mark model layer boundaries. Colored area is constrained by seismic rays. Inverted black triangle mark OBS and LSS positions. Thick blue lines mark the interfaces where reflections are observed on the wide-angle records. Black dotted lines correspond to isocontours. Vertical red lines indicate crossing profiles. Vertical exaggeration is 1:3.

Refracted events in the continental crust middle-crust Pg2 in light-blue, lower-crust Pg3 in blue and $\mathrm{Pn}$ in violet are relatively strong and allow to constrain the crustal structure from -160 to $0 \mathrm{~km}$ model-distance (Figure 9). Pn arrivals refracted from as deep as $30 \mathrm{~km}$ beneath the un-thinned 
continental margin traveling at $8 \mathrm{~km} / \mathrm{s}$ apparent velocity. PmP arrivals from $150-160 \mathrm{~km}$ offset reflect from the hinge-line where the continental crust begins to thin.

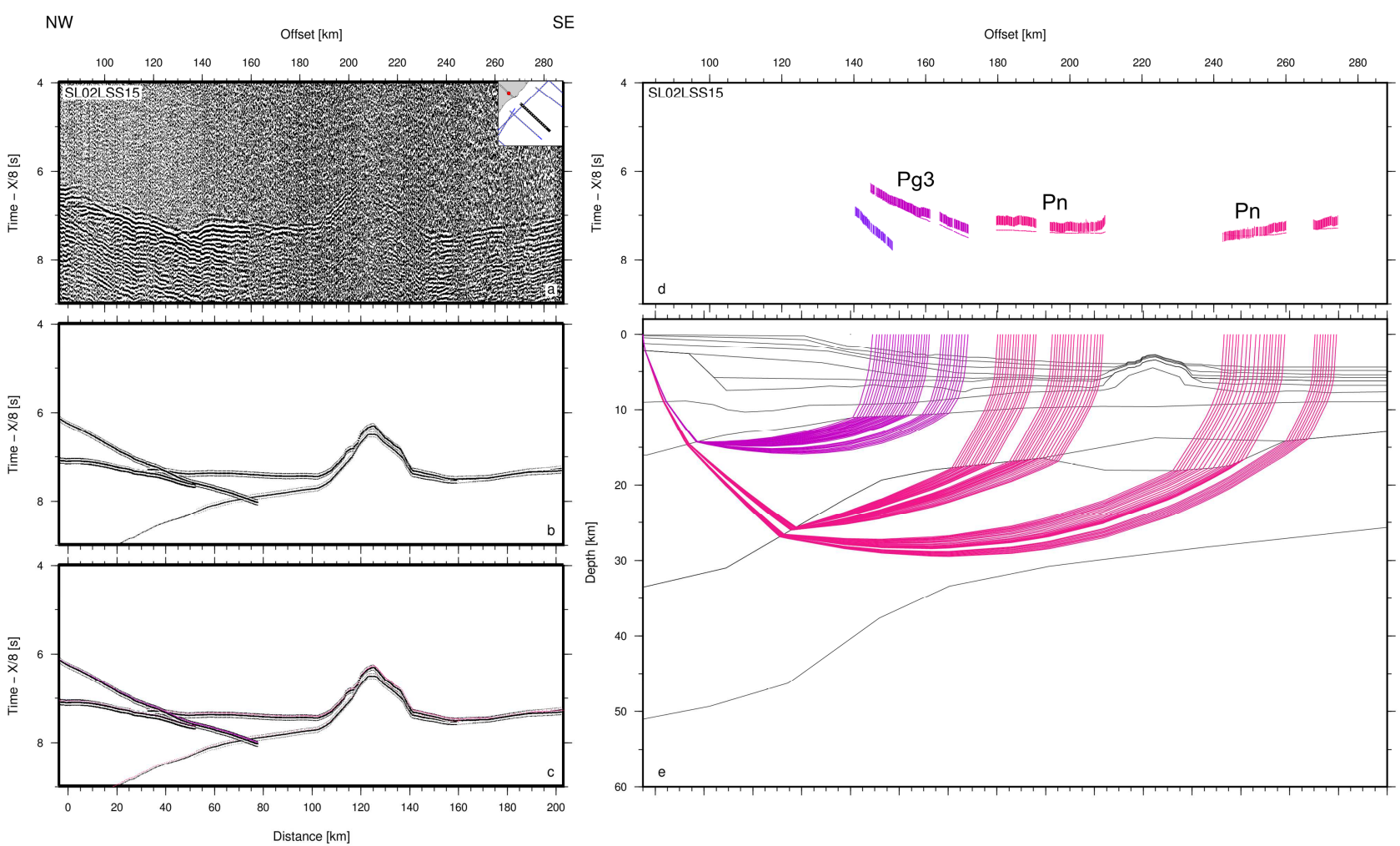

Figure 9: SLO2LSS15 on profile SLO2 on the SFB/SAB contact. a) Seismic record; b) Synthetics; c) Color coded synthetic; d) Color coded observed travel-times overlain by predicted times in black; e) Seismic rays. On a, b, c, and d, travel-time is reduced by a velocity of $8 \mathrm{~km} / \mathrm{s}$.

From SL02OBS15 onward, the full subsurface sedimentary, crustal and mantellic sequence is imaged from shots at the vertical of each OBS to offsets reaching $110 \mathrm{~km}$. The SL020BS14 (Figure 10) shows the example of this part. In addition to clear Pg1, Pg2, Pg3, Pu, Pn (mostly) first arrivals (represented with blue, violet and magenta shades), Ps1 to Ps6 sedimentary refracted arrivals, traveling with apparent velocity increasing from less than $2 \mathrm{~km} / \mathrm{s}$ (close to the water-cone) up to 4 $\mathrm{km} / \mathrm{s}$, are observed as secondary arrivals (represented with red, orange, yellow, and light-green shades). At $\sim 60 \mathrm{~km}$ distance, the Ps5 disappears, and the profile continues seawards with only 5 sedimentary layers. Furthermore, at near-critical incidence, high-amplitude reflections are observed, particularly from the tops of the lower crust Pg3P, unknown unit PuP, and Moho PmP on the seaward-side of OBSs. The Pg1 phase presents the shortest offset range (from $~ 7.5$ to $20 \mathrm{~km}$ offset), and the largest curvature indicative of large velocity gradient. The Pg2 extends from 20 to $\sim 40 \mathrm{~km}$ offset and Pg3 from 45 to $\sim 80 \mathrm{~km}$ offset and the lowest apparent velocity gradient.

In the distal part, from 90 to $140 \mathrm{~km}$ model distance, as shown in SL02OBS07 (Figure 11), the Ps1 to Ps4 remain weak and almost undistinguishable refracted arrival phases that are recorded as a fan of second arrivals with slightly increasing velocities and relatively low velocity-gradients that 
emerges from the water cone. The Ps5 refraction shows considerably higher amplitude and apparent velocity: the exact nature of the S6 layer represented by this phase must be further examined from the pre-stack depth migration of the MCS data, for instance. In the distal oceanic part, the Pg1, $\operatorname{Pg} 2$ and Pg3 refracted phases form a relatively continuous event in both amplitude and apparent velocity, without sharp inflections indicative of major velocity changes between layers. The $\mathrm{Pu}$ phase spans from 90 to $140 \mathrm{~km}$ offset and has an apparent velocity close to $\mathrm{Pg} 3$. Pn is observed

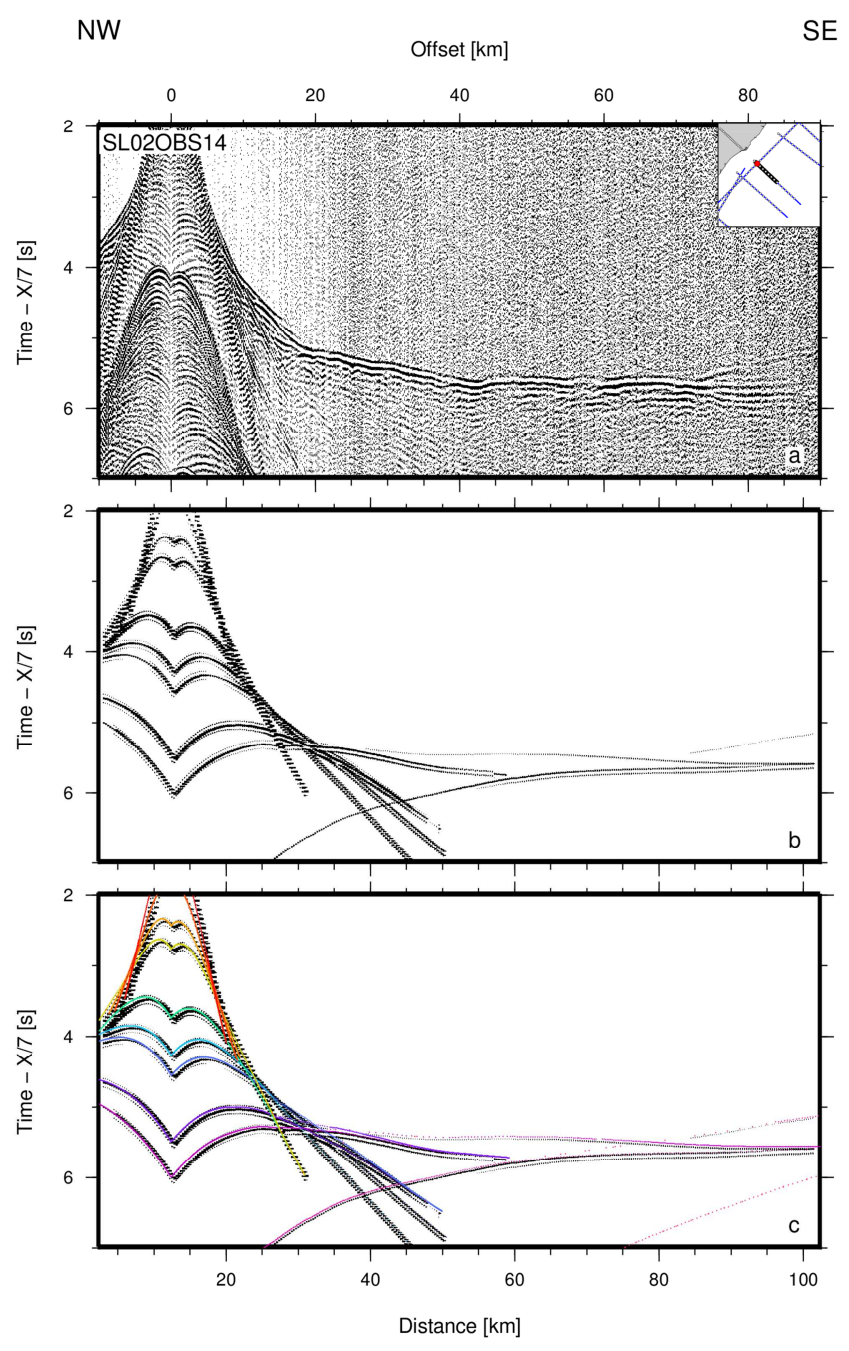

SE

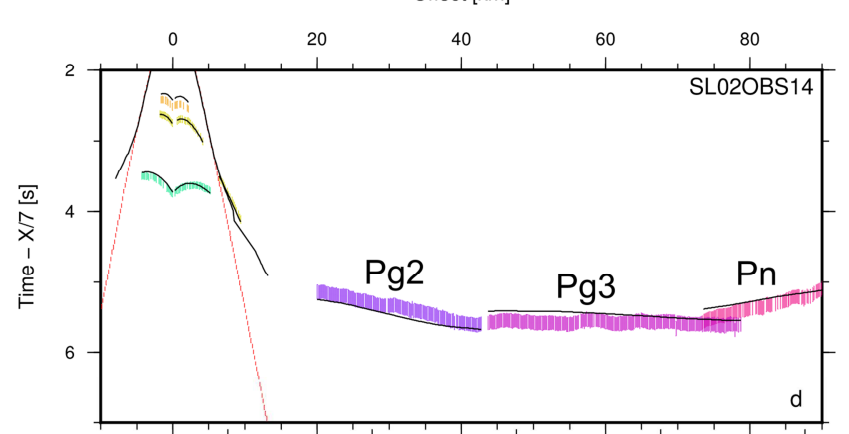

emerging at $\sim 75 \mathrm{~km}$ with an apparent velocity increasing from 7.9 to more than $8.15 \mathrm{~km} / \mathrm{s}$ and large amplitude variations both along offset and OBSs.

Figure 10: SLO2OBS14 on profile SL02 on the SAB. a) Seismic record; b) Synthetics; c) Color coded synthetic; d) Color coded observed travel-times overlain by predicted times in black; e) Seismic rays; f) MCS time migrated section and color-coded model interfaces. On a, b, c, and d, travel-time is reduced by a velocity of $7 \mathrm{~km} / \mathrm{s}$.

Velocity Model

390 From SL02 wide-angle data, we digitized 24009 events and interpreted their respective phases.

391 Travel-time uncertainty was estimated on the SL02OBS and SL2LSS records and fixed at 0.030 s

392 for the water, $0.050 \mathrm{~s}$ for the sedimentary arrivals increasing to $0.100 \mathrm{~s}$ for the crustal and mantellic 
arrivals. The model explains the travel-time and phase of 21166 events or $88 \%$ of total picks, with a

394 global RMS travel-time residual of 0.138 s. Given our events individual uncertainty, the model 395 results in a normalized chi-squared of 1.892. Generally, the SL02 model correctly explained the 396 SL02OBS and SL02LSS with chi-squared and rms values acceptable (Table 2).

\begin{tabular}{ccccc} 
phase & npts & Trms & $\begin{array}{c}\text { chi- } \\
\text { squared }\end{array}$ & $\begin{array}{c}\text { Uncertainty } \\
\text { (ms) }\end{array}$ \\
water & 2708 & 0.029 & 0.084 & 30 \\
Ps1P & 21 & 0.013 & 0.017 & 50 \\
Ps2P & 436 & 0.070 & 0.496 & 50 \\
Ps3P & 305 & 0.085 & 0.727 & 50 \\
Ps4P & 298 & 0.067 & 0.444 & 50 \\
Ps5P & 122 & 0.154 & 2.394 & 50 \\
Ps6P & 277 & 0.102 & 1.042 & 50 \\
Pg1 & 43 & 0.113 & 1.308 & 100 \\
Pg1P & 32 & 0.186 & 3.570 & 100 \\
Pg2 & 347 & 0.167 & 2.793 & 100 \\
Pg2P & 30 & 0.052 & 0.282 & 100 \\
Pg3 & 1893 & 0.131 & 1.706 & 100 \\
Pg3P & 1980 & 0.121 & 1.470 & 100 \\
Pn & 7194 & 0.121 & 1.462 & 100 \\
PmP & 1083 & 0.145 & 2.101 & 100 \\
\hline Pu & 38 & 0.052 & 0.274 & 100 \\
PuP & 1078 & 0.243 & 5.906 & 100
\end{tabular}

397 Table 2: Reflected or refracted phase name, number of explained events, residual mean-square, and normalized chi398 squared value.

400 The final velocity model of profile SL02 images the depth geometry of all sedimentary, crustal and 401 mantellic layers to a depth of around $34 \mathrm{~km}$ (Figure 8A). According to the interpretation of the 402 wide-angle data described above the velocity structure of SL02 model was modeled using four to 403 six layers of sediments. These sedimentary layers are characterized by relatively homogeneous P404 wave velocities all along the SL02 model with no strong lateral variation. This sedimentary deposit 405 in the SAB starts at $-120 \mathrm{~km}$ model distance and reaches a maximum of $7 \mathrm{~km}$ of thickness between $406-50$ and $-20 \mathrm{~km}$ model distance until $2.5 \mathrm{~km}$ at the SE in the distal basin (Figure 8A). 


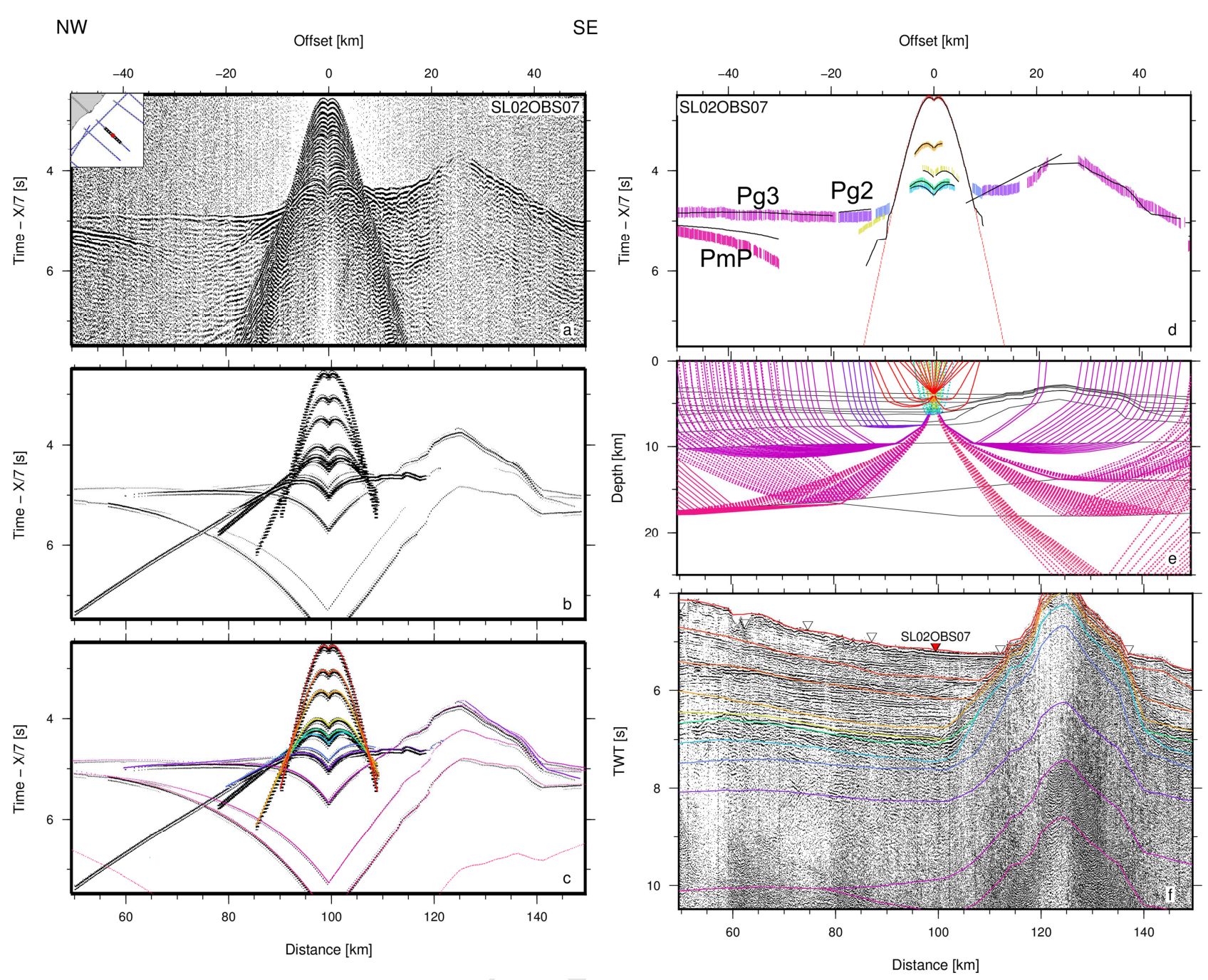

Figure 11: SLO2OBSO7 on profile SLO2 on the SAB. a) Seismic record; b) Synthetic; c) Color coded synthetic; d) Color coded observed travel-times overlain by predicted times in black; e) Seismic rays; f) MCS time migrated section and color-coded model interfaces. On $a, b$, c, and d, travel-time is reduced by a velocity of $7 \mathrm{~km} / \mathrm{s}$.

412 The P-wave velocities of the sedimentary sequence show an increasing trend: the top velocity at the 413 seafloor is $1.65 \mathrm{~km} / \mathrm{s}(\mathrm{S} 1)$ and the maximum velocity $4.7 \mathrm{~km} / \mathrm{s}$ is reached at the base of the 414 sedimentary sequence (S6).

$415 \mathrm{~S} 1 \mathrm{has}$ top and bottom $\mathrm{P}$ wave seismic propagation velocities of $1.65 \mathrm{~km} / \mathrm{s}$ to $1.85 \mathrm{~km} / \mathrm{s}$. S2 has a 416 negligible vertical gradient and propagation velocity of $2.2 \mathrm{~km} / \mathrm{s}$ on the western end of the profile 417 that gradually decreases up to $2.10 \mathrm{~km} / \mathrm{s}$. S3 has top and bottom velocities from $2.60 \mathrm{~km} / \mathrm{s}$ to 2.70 $418 \mathrm{~km} / \mathrm{s}$ with a small gradient decrease towards the continental slope. S4 has top and bottom velocities 419 from $3.00 \mathrm{~km} / \mathrm{s}$ to $3.25 \mathrm{~km} / \mathrm{s}$. S5 has top and bottom velocities from $4.10 \mathrm{~km} / \mathrm{s}$ to $4.20 \mathrm{~km} / \mathrm{s}$. S6 has 420 constant top and bottom velocities from $4.60 \mathrm{~km} / \mathrm{s}$ to $4.70 \mathrm{~km} / \mathrm{s}$. 
Beneath this sedimentary record, the top of the basement corresponds to a rough interface and the modeled basement structure comprises four crustal layers: upper crust, middle crust, lower crust and an anomalous body under the volcano. The upper crust has a thickness between $1.0 \mathrm{~km}$ and $2.0 \mathrm{~km}$ on the presumed oceanic basin and increases to $3.0 \mathrm{~km}$ at the continental slope, with velocities at the top and bottom from $4.75 \mathrm{~km} / \mathrm{s}$ to $5.1 \mathrm{~km} / \mathrm{s}$.

The middle crust has a regular thickness of $3.0 \mathrm{~km}$ for all the profile, except under the volcano, where it reaches almost $5.0 \mathrm{~km}$ with velocities at the top and bottom from $6.4 \mathrm{~km} / \mathrm{s}$ to $6.5 \mathrm{~km} / \mathrm{s}$ on the continental slope and from $6.2 \mathrm{~km} / \mathrm{s}$ to $6.3 \mathrm{~km} / \mathrm{s}$ on the distal basin. The lower crust is $8.0 \mathrm{~km}$ thick at the northwestern end of the model and completely thins out to $4.0 \mathrm{~km}$ thick towards the ocean, with velocities at the top and bottom from 6.90 to $7.10 \mathrm{~km} / \mathrm{s}$ along all the profile, except in the necking zone, between 0 and $50 \mathrm{~km}$ model distance, where there is a slight increase of the velocities in the middle and the lower crusts: the middle crust passes from $6.10-6.30 \mathrm{~km} / \mathrm{s}$ to 6.30 $6.50 \mathrm{~km} / \mathrm{s}$ and the lower crust, from $6.90-7.10 \mathrm{~km} / \mathrm{s}$ to $7.30-7.50 \mathrm{~km} / \mathrm{s}$ (Figure 8B). Note that there is also a thick anomalous body, not located below the Necking Zone as along SL01 profile, but below the Moho in the volcanic edifice area. It has a thickness of $8 \mathrm{~km}$ and velocities between 7.3$7.4 \mathrm{~km} / \mathrm{s}$.

\section{Evaluation of the models}

\section{Gravity modelling}

439 A 2-D model consisting of homogeneous density blocks was constructed from the seismic velocity 440 model: the P-wave velocity is converted to densities according to Ludwig et al. (1970) except 441 onshore in the continental crust where conversion follows Christensen and Mooney (1995). The 442 resulting density ranges from 2200 to $2500 \mathrm{~kg} / \mathrm{m}^{3}$ in the basin, 2600 to $2750 \mathrm{~kg} / \mathrm{m}^{3}$ in the crust and 4433000 to $3170 \mathrm{~kg} / \mathrm{m}^{3}$ in the under-crustal unit. The mantle density is set at $3420 \mathrm{~kg} / \mathrm{m}^{3}$. The model is 444 extended down to $80 \mathrm{~km}$ where isostatic compensation may be reached, and the modeled free-air anomaly is compared to measured gravity anomaly along the SL01 and SL02 profiles (Figure 12).

446 The SL01 model fits relatively well (within less than $10 \mathrm{mGal}$ ) the gravity data acquired offshore 447 during the SALSA survey, except for the continental slope (where the model is less constrained) 448 where there's a misfit of $17 \mathrm{mGal}$. Free air gravity from satellite data (Sandwell et al., 2014) 449 extracted along the profile and 10, 20, and $30 \mathrm{~km}$ cross-line presents broad (>50 km wavelength) 450 along profile and lateral scatter amplitude variations of $+/-10 \mathrm{mGal}$ (Figure 12c and d).

451 The SL02 model fits relatively well (within less than $25 \mathrm{mGal}$ ) the gravity data acquired offshore 452 during the SALSA survey, except for the seamount where there's a misfit of $65 \mathrm{mGal}$, probably due 453 to the 3D effects. The calculated gravity anomaly falls well within the values observed on parallel 
454 profiles extracted north and south of the profile (Figure 12a and b), derived from satellite gravity 455 measurements (Sandwell et al., 2014). Due to the high altitude of the satellite, lower wave-length 456 are not well recorded.

457
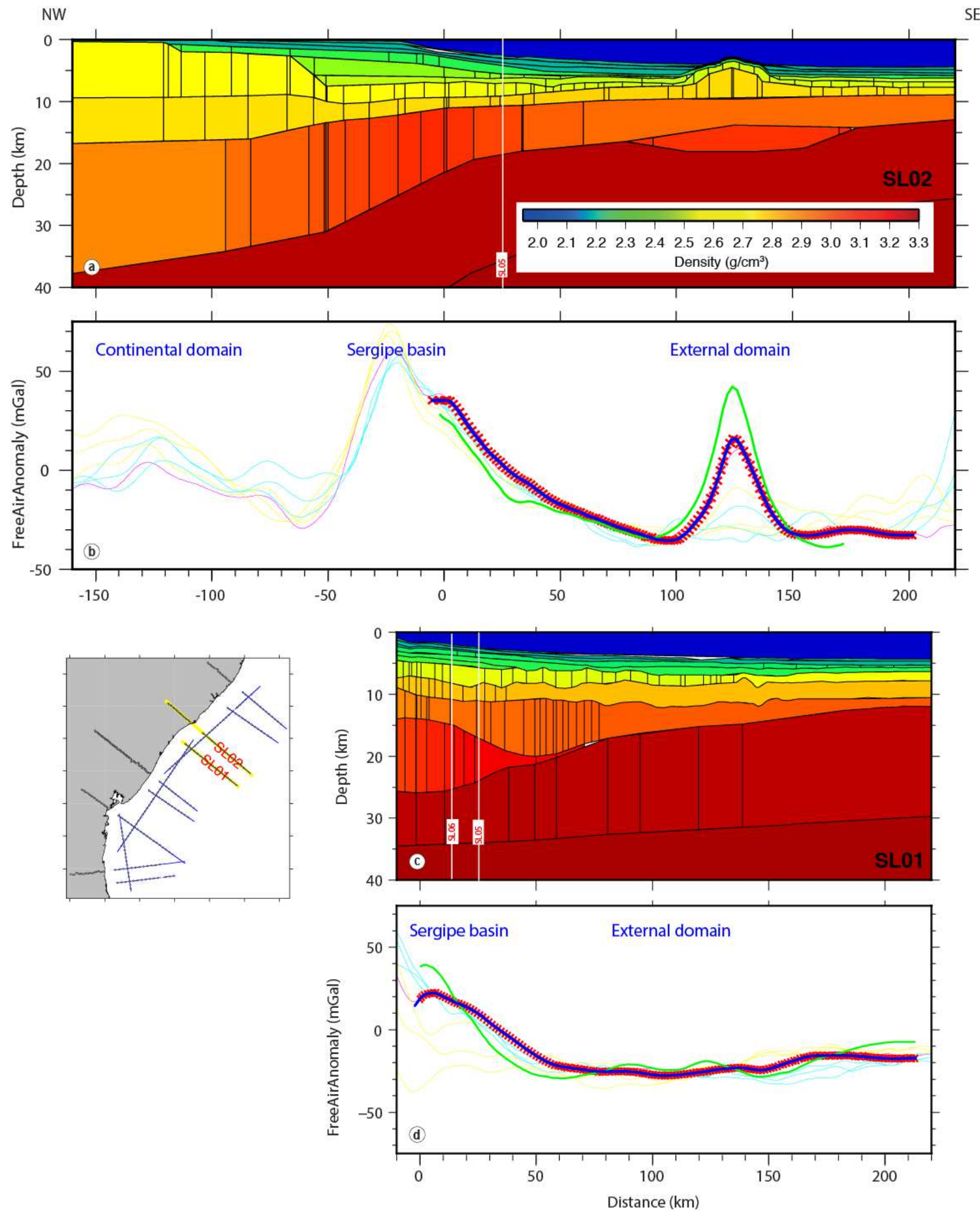
Figure 12: Gravity modeling along SL02 profile. a) Density model up to a depth of $40 \mathrm{~km}$ overlain by interfaces from wide-angle modeling. b) Free-air gravity anomaly observed (Pavlis et al., 2012 for the offshore data and BGI: International Gravimetric Bureau, for the land data) along the SLO2 profile (red crosses) and laterally 10, 20 and 30 $\mathrm{km}$ ( $S W$-ward as yellow lines, NE-ward as cyan lines), measured during the SALSA experiment (blue line) and calculated (green line). Gravity modeling along SLO1 profile. c) Density model up to a depth of $40 \mathrm{~km}$ overlain by interfaces from wide-angle modeling. d) Free-air gravity anomaly observed (Pavlis et al., 2012) along the SL01 profile (red crosses) and laterally 10,20 and $30 \mathrm{~km}$ (SW-ward as yellow lines, NE-ward as cyan lines), measured during the SALSA experiment (blue line) and calculated (green line).

\section{Hitcount, spread, and resolution}

Interface depth node spacing as well as velocity node spacing is key to model the lateral variations of the seismic velocity with sufficient resolution, but without introducing spurious and unwarranted complexity. Although all synthetics section correctly reproduces the observed amplitude on the wide-angle data (Figures 5 to 11), suggesting a good parameterization of the model, we perform evaluation tests of the P-wave velocity models: hitcount, Spread Point Function (SPF) and resolution (Figure 13).

The interface nodes are spaced at less than $2 \mathrm{~km}$ on the seafloor where depth is well constrained by multi-beam bathymetry. Node spacing increases to $2.5 \mathrm{~km}$ for the three first sedimentary layers then $5 \mathrm{~km}$ for the deepest sedimentary layers and the basement where the interface geometry is well constrained in twt from the MCS data, then $10 \mathrm{~km}$ for the middle crust, $15 \mathrm{~km}$ for the lower crust and Moho, $30 \mathrm{~km}$ and $50 \mathrm{~km}$ for the intra-mantellic reflectors. The velocity nodes are not spaced evenly but located where velocity changes are warrant by the observed wide-angle records, resulting in node spacing ranging from 30 to $350 \mathrm{~km}$. The total standard deviation for depth nodes and velocity nodes is $6.229 \mathrm{~km}$ and $1.785 \mathrm{~km} / \mathrm{s}$, respectively. Most interface and velocity nodes in our experiment produce a hit-count larger than 3000 rays (Figure 13) with exception of the edges of our survey and the middle crust. The Spread Point Function (Figure 13) is indicative for a given velocity variation of the resulting travel-time variations when taking the different ray paths into account. Depth and velocity node SPF is relatively homogeneous in the models except in the lower crust along SL02 profile in the transition of the continental to the presumed oceanic domain. Finally, the diagonal terms of the resolution matrix are a measurement of the spatial averaging of the true earth structure by a linear combination of model parameters (Zelt 1999). Typically, resolution matrix diagonals greater than $0.5-0.7$ are said to indicate reasonably well-resolved model parameters (e.g. Lutter and Nowack 1990). The major part of the interface and velocity nodes present good resolution (>0.7). Resolution is poorest at the transition zone, in the lower crust, in the upper crust at the SAB, and under the volcanic edifice (Figure 13). 

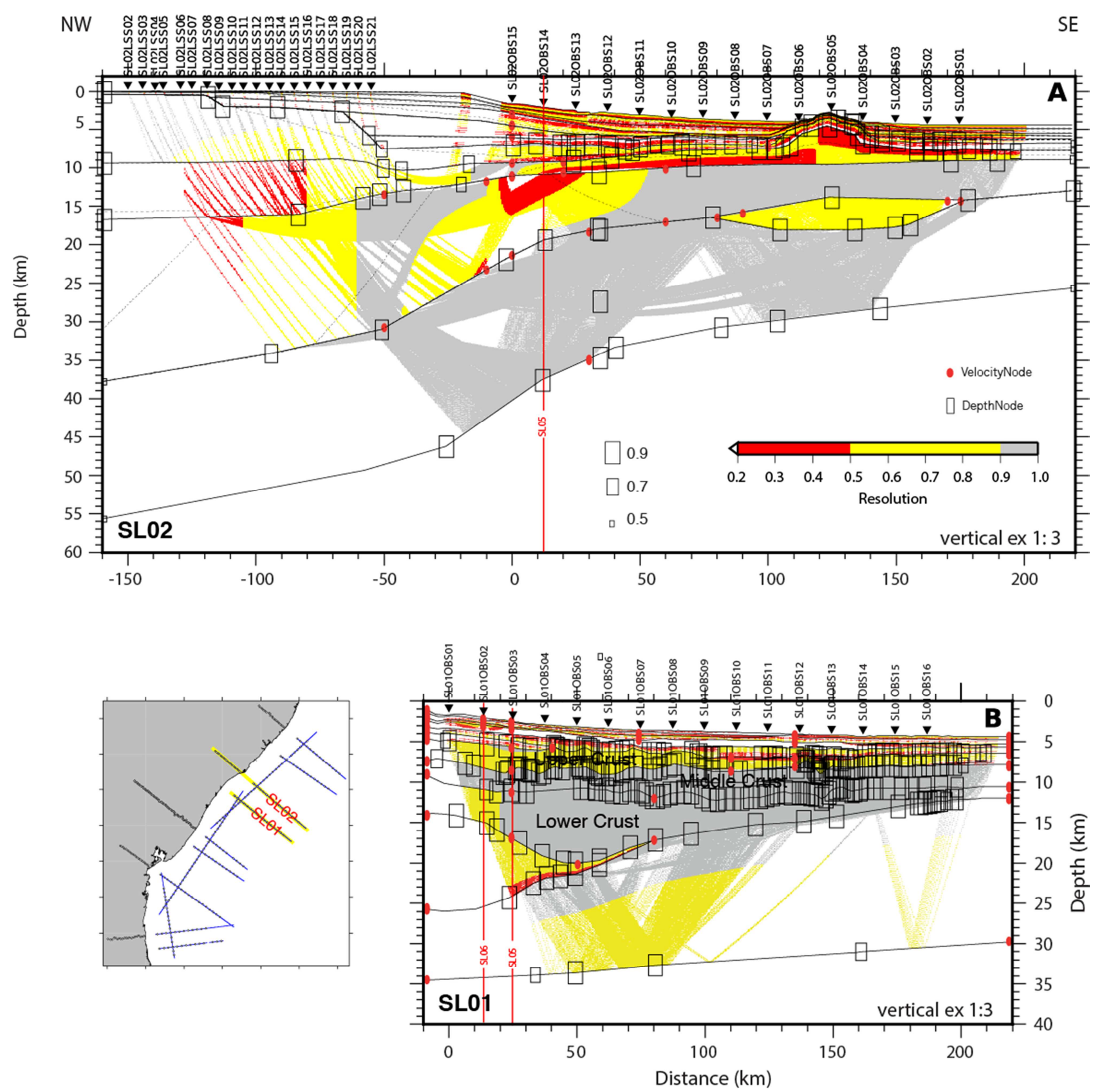

Figure 13: Evaluation of the wide-angle models SLO1 (A) and SLO2 (B): Resolution of velocity (gridded and colored).

There are zones that were not imaged due to the lack of ray coverage.

\section{MCS data pre-stack depth migration (PSDM)}

498 To verify the accuracy of the wide-angle velocity model, the MCS data is pre-stack depth migrated 499 and residual move-out analysis is performed. The pre-processing sequence is identical to the MCS 500 data time processing, and includes geometry, wave-equation multiple attenuation, shot-gather 501 predictive deconvolution, time variant band-pass filter, and random multiple attenuation. The 502 PSDM processing is undertaken using the Seismic Unix package (Stockwell Jr., 1999; Cohen and 503 Stockwell Jr., 2010). The PSDM consists in 2 steps: ray tracing and seismic data depth migration. 
First, the velocity model is utilized to compute travel-time tables regularly spaced at $150 \mathrm{~m}$ along the profile by paraxial ray tracing on a $50 \times 25 \mathrm{~m}$ spaced grid, then travel-times in shadow zones are compensated by solving the eikonal equation. Secondly, common offset Kirchhoff depth migration is performed: Migrated traces are output as common image gathers (CIG) binned at $25 \mathrm{~m}$ with 30 offset-classes between 249 and $4596 \mathrm{~m}$ at $150 \mathrm{~m}$ spacing. Dip-independent velocity analysis can then be performed on the migrated CIG by analyzing residual move-out. Hence, if the velocity model used for migration is close to the true medium velocity, all common offset migrated panels map the recorded seismic events to the same reflector depth, else the move-out from near to far offset translates into an interval velocity correction (Liu and Bleistein, 1995). Figure 14 presents the PSDM section and CIG gathers extracted every $7.5 \mathrm{~km}$ along the two profiles. Moreover, depth migrated gathers are excellent records of amplitude variations with offset (AVO), and therefore are indicators of in-situ rheological changes. The residual move-out behavior together with the seismic character from PSDM images are key elements to locate accurately major geological contacts, moreover with higher horizontal resolution when compared to the OBS records.

518 SALSA01 (Fig. 14C) and SALSA02 (Fig. 14A) were migrated up to a depth of $18 \mathrm{~km}$, showing 519 very good resolution in the sedimentary layers, and a good resolution in the crust, with good agreement between strong reflectors and their wide-angle estimated depths. The SAB shows a sedimentary structuration that can be subdivided between upper and lower packages. Upper sediments represent the first 4 layers, which are finely stratified and made of low amplitude continuous reflectors while deeper reflectors have a stronger amplitude character. The entire sedimentary package is clearly interrupted by the volcanic edifice. The upper package varies in thickness from about $1.5 \mathrm{~km}$ at the continental slope, $3 \mathrm{~km}$ at NW side of the volcano and $2 \mathrm{~km}$ at SE side, at the presumed oceanic basin. The lowest sedimentary package is composed by 2 layers that merge into 1 layer, at $40 \mathrm{~km}$ model distance on SL01, and at the NW side of the volcano at SL02. The top of this package shows the strongest and most continuous reflector in the MCS data. This reflector represents the base of the Calumbi Formation. A recede at the sea level in the end of the Coniacian controlled the erosion of the underlying sequences. This regional erosional event is represented by the so called Pre-Calumbi Formation (probably Santonian, 86 Ma) unconformity at 532 the base of the Piaçabuçu Group (Mohriak et al., 1998; Campos Neto et al., 2007). This 533 unconformity can be observed as the most remarkable reflector, and is interpreted as a regional 534 angular, intra-Cretaceous unconformity in the platform that is almost flat-lying in the deep-water region and overlies horizontal sedimentary layers (Mohriak et al., 1998, 2000).

The basement is composed by chaotic seismic facies in the MCS data. Below the basement it is impossible to differentiate any seismic facies or structure. Unlike the profile SL01 (Figure 4), no reflector corresponding to the Moho is observed in the profile SL02. 

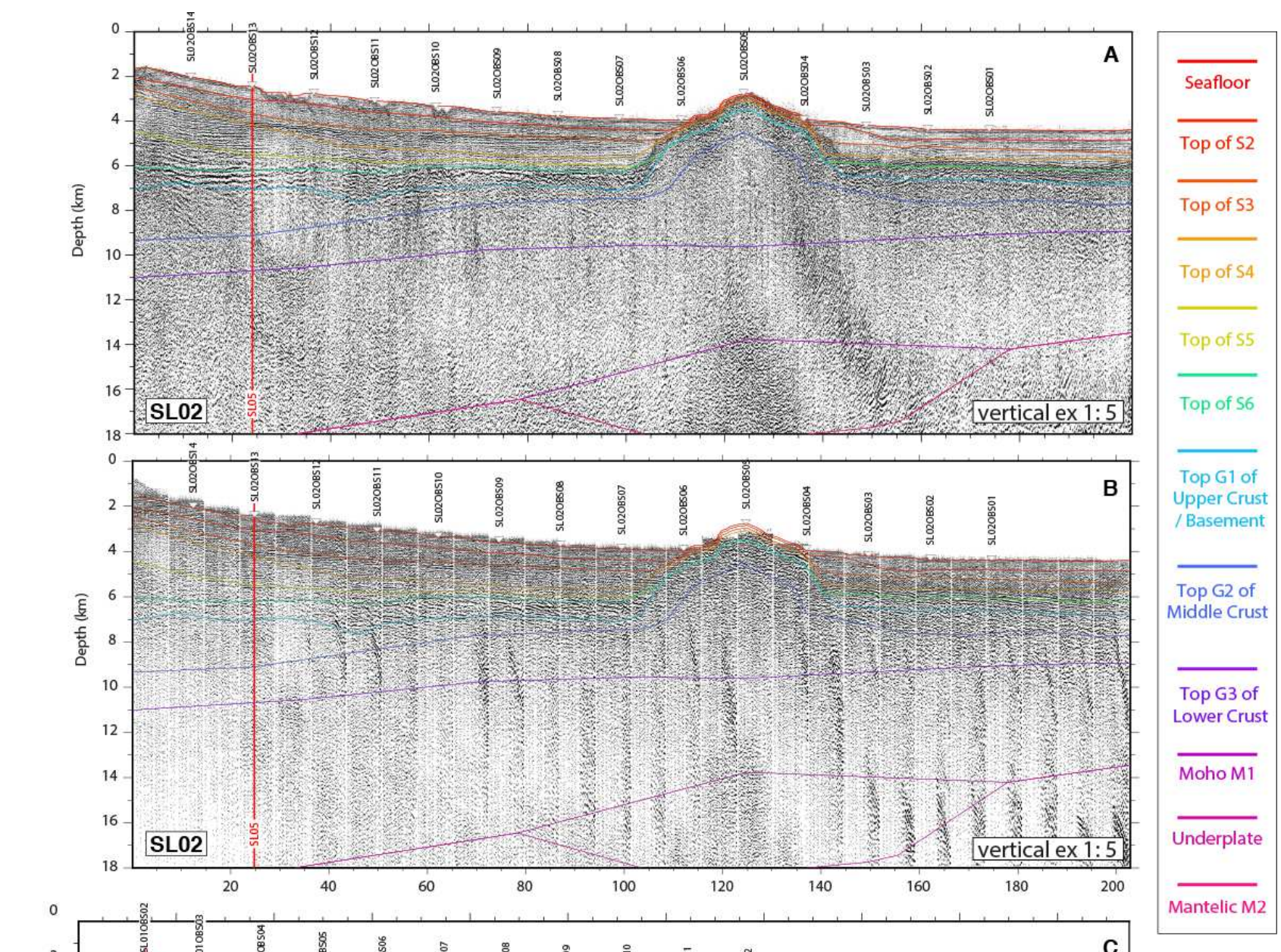

c

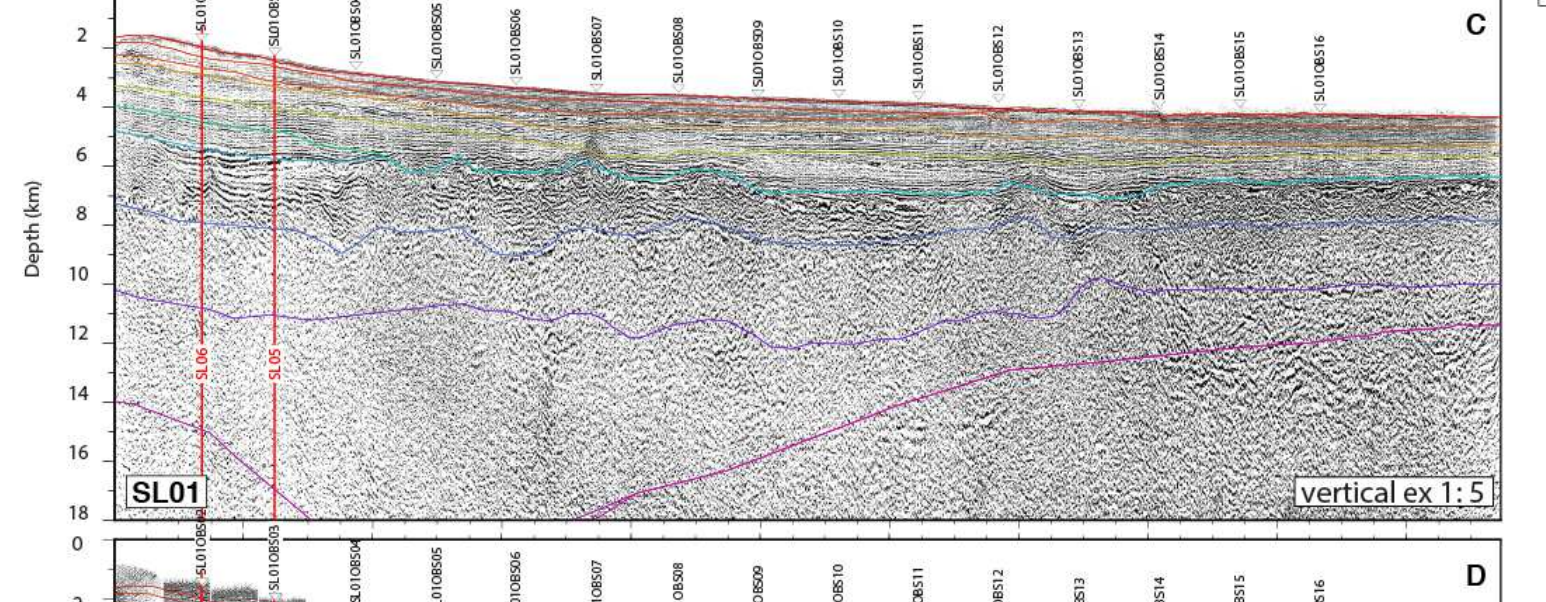

541 Figure 14: a) Pre-stack depth migrated record section of MCS data along SL02 profile. Model's interfaces are

542 represented with continuous lines. The intersections with the SALSA dataset are indicated by red line. Vertical 
exaggeration is 1:5. b) Residual move-out of MCS data along SLO2 profile. Common image gathers are spaced every

$5447.5 \mathrm{~km}$. c) Pre-stack depth migrated record section of MCS data along SL01 profile. Vertical exaggeration is 1:5. b)

545 Residual move-out of MCS data along SL01 profile. Common image gathers are spaced every $7.5 \mathrm{~km}$. Vertical 546 exaggeration is 1:5.

\section{Discussion}

549 In order to constrain the nature of the crust, 1D crustal velocity- depth (Vz) profiles were extracted 550 underneath the top of the basement at a $10 \mathrm{~km}$ interval from the final velocity models (Figure 15). 551 These Vz graphs can be compared to compilations for typical continental crust (Christensen and 552 Mooney, 1995) and Atlantic-type oceanic crust (White et al., 1992) that allow to discuss the 553 properties of crust and to establish the lateral segmentation along the profiles.

554 On the base of this analysis of the final models and these $\mathrm{Vz}$ graphs, three distinct domains can be 555 distinguished: 1. Unthinned Continental Domain; 2. a domain of crustal thinning, the Necking 556 Domain; and lastly, 3. an external distal domain interpreted to be of oceanic nature (Figure 15). No 557 transitional domain is defined in the $\mathrm{SAB}$, the transition between the thinned continental and 558 oceanic crusts is direct. 


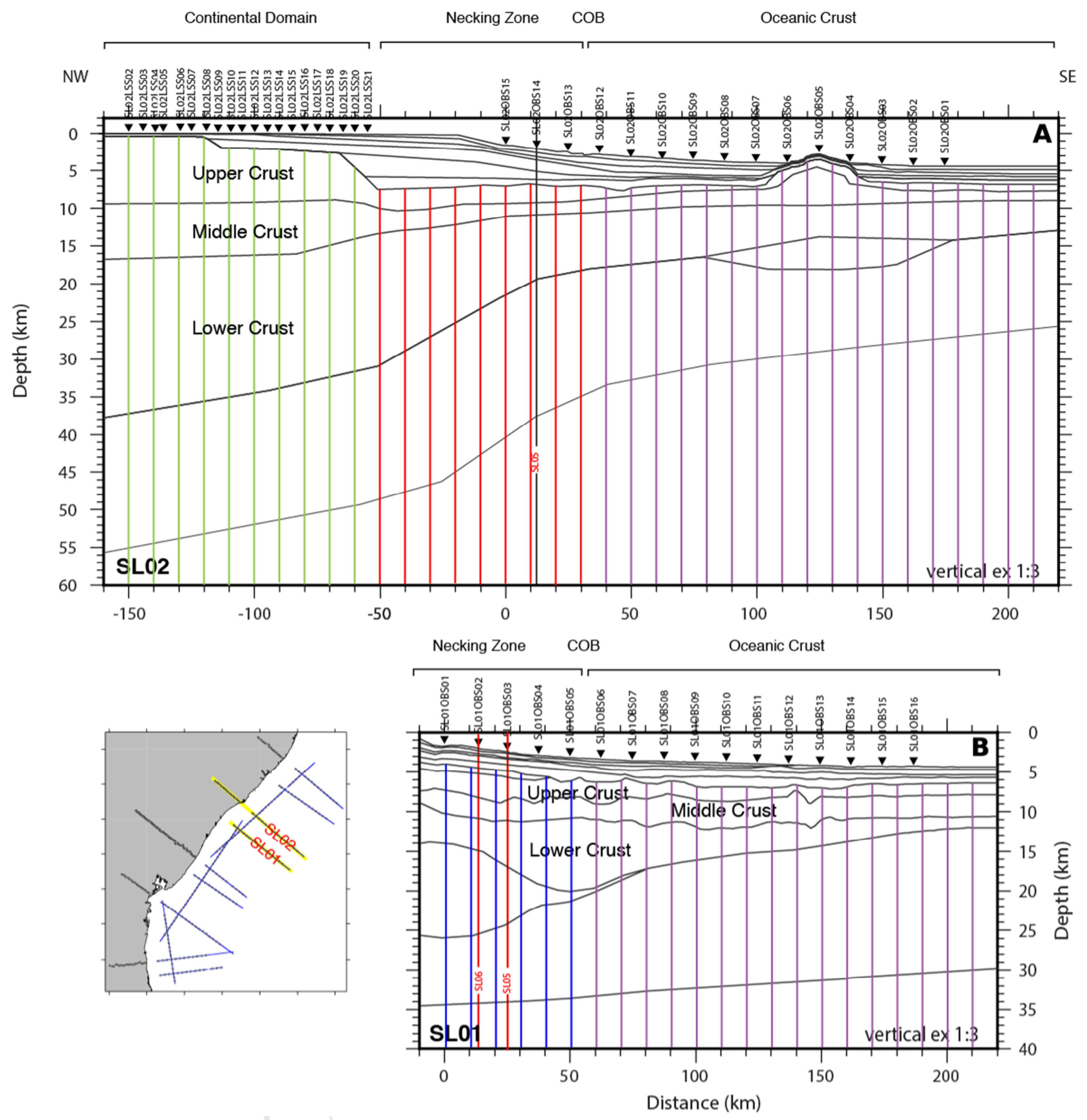

562 Figure 15: Distribution of 1-D velocity profiles extracted from the final P-wave interval velocity model and color coded 563 according to segmentation along the SLO2 (A) and SLO1 (B) profiles

\section{Unthinned Continental Domain}

565 This domain is essentially based on the profile SL02 data, taking into consideration that it is the 566 unique profile with landstations.

567 As the inland proximal part of the profile, between the landstations and the OBSs, is not completely constrained by the seismic rays, the modeling of the Unthinned Continental domain, was also constrained by additional information obtained from the crossing with profile SL05 (Evain, et al., In 
570 prep.), and bibliographical information (Chang et al., 1992; Feijó et al., 1994 ; Mohriak et al., 571 1995, 1998, 2000; Blaich et al., 2008 ; Soares et al., 2010 ; Tavares et al., 2012 ; de Lima et al., 572 2015).

573 In the Continental domain, the Moho is 27 to $37 \mathrm{~km}$ depth below basement (Figure 16). The 574 comparison of the 1D velocity profiles with a worldwide compilation of the continental crust 575 (Christensen and Mooney, 1995) clearly shows similarities both in velocities and gradients with our 576 results (Figure 16). 


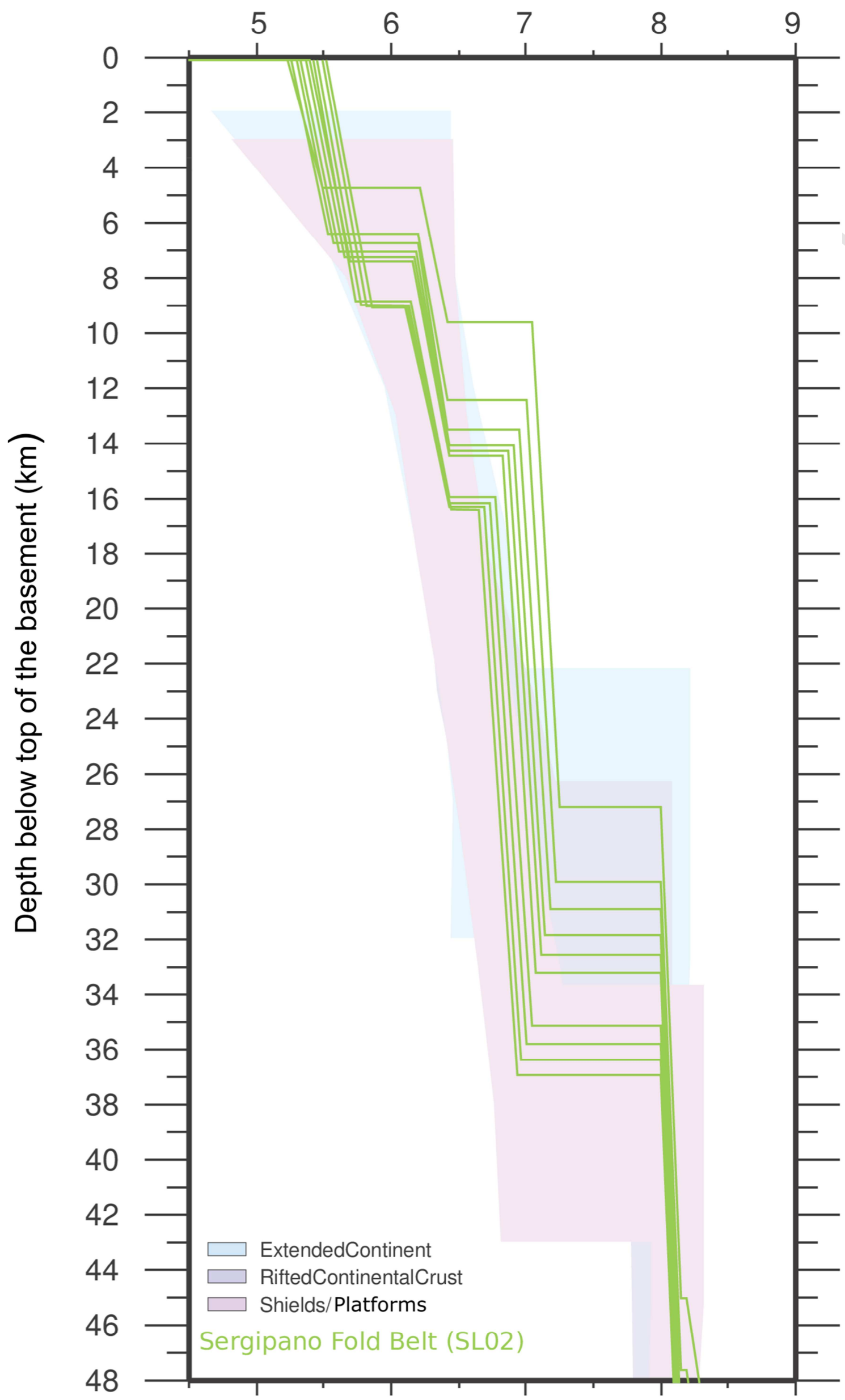


Figure 16: Compilation of $1 D$ velocity-depth profiles extracted below the top of the basement (Vz) in the domains of unthinned continental crust. The light blue areas correspond to averaged velocity profiles for continental crust (Christensen and Mooney, 1995).

At the SL02 profile, in the Continental domain, the top of the upper crust, the basement, is at the surface until $-120 \mathrm{~km}$ distance model, then it deepens, forming three "stairs", first at $-120 \mathrm{~km}$ distance model, where it deepens to $2.5 \mathrm{~km}$ deep, and then at $-60 \mathrm{~km}$ distance model it deepens to 8 $\mathrm{km}$ deep (Figures 15 and 16). The upper layer has velocities between 5.50 and $5.90 \mathrm{~km} / \mathrm{s}$, that decreases seawards. The topography of the interface between the upper and middle crust is almost regular for all along the profile, and the velocities of the middle crust range from 6.10 to $6.50 \mathrm{~km} / \mathrm{s}$. The base of the lower crust corresponds to the Moho, whose depth decreases smoothly from 37 to $33 \mathrm{~km}$. Its velocities at the top increase from $6.60 \mathrm{~km} / \mathrm{s}$ in most continental part, to $7.30 \mathrm{~km} / \mathrm{s}$ seawards, near to the Necking Zone and its velocities at the base, range from $6.90 \mathrm{~km} / \mathrm{s}$ at the continental domain to $7.50 \mathrm{~km} / \mathrm{s}$ near the Necking Zone.

592 The deep seismic refraction experiment carried out in the Pernambuco Province, northwards (Figure 1) (Soares et al., 2010; Tavares et al., 2012; Lima et al., 2015) shows a structure of the lithosphere, with 2 layers separated at about $16 \mathrm{~km}$ depth, with a velocity of 5.75 to $6 \mathrm{~km} / \mathrm{s}$ at the top and 6.2 to $6.3 \mathrm{~km} / \mathrm{s}$ at the base of the upper crust, and 6.4 to $6.5 \mathrm{~km} / \mathrm{s}$ at the top and 6.75 to $6.90 \mathrm{~km} / \mathrm{s}$ at the base of the lower crust, for a total continental crust thickness of about $32 \mathrm{~km}$. In terms of velocities, this structure is quite similar to that found in SL01 and SL02. The upper layer found by these authors, would correspond to the upper and middle layer of SL01 and SL02.

599 These similarities put into question the proposition that the SFB is a Neoproterozoic fold-thrust belt produced by inversion of a passive margin basin located at the northeastern edge of the ancient Sao 601 Francisco plate (Almeida et al., 1977 ; D'el-Rey Silva, 1999) and constituted by a $42 \mathrm{~km}$ thick crust 602 (Oliveira et al., 2008) and reinforces the idea that the SFB was possibly on the margin of the 603 Palaeoproterozoic Pernambuco-Alagoas Block (Oliveira et al., 2010), and was attached to the Sao 604 Francisco Craton during the Brasiliano ( 600 Ma) orogenic event (Davison and Santos, 1989; Silva 605 Filho, 1998). These results put the limit clearly between the Sao Francisco Craton and the 606 Palaeoproterozoic Pernambuco-Alagoas Block on the Vaza Barris transfer zone, considering it as a major structural fault.

\section{Necking Zone:}

609 The necking zone goes from $-55 \mathrm{~km}$ to $25 \mathrm{~km}$ profile distance. On profile SL02, throughout the necking zone, the total crustal thickness, without the water column ( 4 km through the COB) and 
sediment cover, thins from $\sim 23 \mathrm{~km}$ to $\sim 10 \mathrm{~km}$. The thickness of the upper crust thins from $10 \mathrm{~km}$ in

612 the limit with the continental domain to only 1 to $2 \mathrm{~km}$ seaward in the limit with the oceanic 613 domain. At the depocenter of the $\mathrm{SAB}$, at $-50 \mathrm{~km}$ distance of the profile, the top of the upper crustal 614 layer deepens to $\sim 8 \mathrm{~km}$ and remains at this depth for all along the profile. The thickness of the 615 middle crust thins from $\sim 7 \mathrm{~km}$ in the limit with the continental domain, to $\sim 2 \mathrm{~km}$ through the 616 necking domain until the COB. The Moho rises from $31 \mathrm{~km}$ depth in the limit with the continental 617 domain to $\sim 18 \mathrm{~km}$ depth in the COB over a distance of almost $100 \mathrm{~km}$ (Figure 8), and the total 618 thickness of the lower crust thins from $19 \mathrm{~km}$ in limit with the continental domain to $8 \mathrm{~km}$ beneath 619 the $\mathrm{COB}$, with a light velocity increase in the middle of the Necking Zone. The lateral velocity change happens only in the lower crust where it changes from 7.0 to $7.3 \mathrm{~km} / \mathrm{s}$ on the top and from 7.25 to $7.5 \mathrm{~km} / \mathrm{s}$ at the base. In the Necking Zone between 30 and $90 \mathrm{~km}$ distance, and 9 and $15 \mathrm{~km}$ depth, there are also packages of intra-crustal reflectors that may correspond to SDRs. Although the base of the crust is much clearer in SL02 than in SL01, without basal intra-crustal reflectors.

The gravity data shows a prominent positive anomaly in the necking zone.

The necking zone of the SL01 is partially constrained in the wide-angle data (Figures 8 and 15), but in the MCS (Figures 4 and 14), it presents a zone of intracrustal reflectors between 4 and 8 $\mathrm{km}$ depth and between 10 and $70 \mathrm{~km}$ model distance. We can recognize few SDRs pattern in this zone, and, in the GXT-ION profiles, a group of deeper reflectors in the lower crust, near the Moho discontinuity, between 20 and $25 \mathrm{~km}$ depth, and between 20 and $80 \mathrm{~km}$ model distance. These reflectors were interpreted by Mohriak et al. (1998) as a gradational passage from the lower crust to the lithospheric mantle. In this same zone, we observe a very irregular topography in the basement, showing some structures that look like volcanic plugs (Mohriak et al., 1995, 1998).

This zone gives a chaotic response in the wide-angle data. Additionally, the fact that this area is a zone with poor data coverage and no inland continuation makes difficult a detailed interpretation of the crustal framework near the base of the crust. However, in wide-angle data, the Pmp is very clear and allows us to make a good interpretation of the Moho discontinuity. It rises from $25 \mathrm{~km}$ depth in the extreme $\mathrm{NW}$ of the profile to $18 \mathrm{~km}$ in the transition of the continental to oceanic crust at $\sim 70 \mathrm{~km}$ distance in the profile (Figure 8). In the lower crust, the array of basal intracrustal reflectors is disposed in an anticlinal pattern that gives an idea of a lenticular shape (figure 8). In this zone, the velocity goes from 7.0 to $7.3 \mathrm{~km} / \mathrm{s}$ laterally. Loureiro et al. (2018) found some similar structures in the profile SL11, located at the Jequitinhonha basin, near a zone of "necking zone wideness" transition.

Buck $(1991,1999)$ reports "a series of basins and ranges in a broad region of continental extension". According to Buck (1999), this pattern, is related to lateral periodic variations in the rate 
645 of extension, which causes the so-called "lithospheric boudinage". This process of boudinage of the

646 lithosphere produces variations on the local isostasy, also called crustal buoyancy (Block and 647 Royden, 1990; Bird, 1991; Buck, 1991, 1999).

648 From the Continental Domain to seawards, the total crustal thickness, without the water 649 column ( $\sim 4 \mathrm{~km}$ through the COB) and sediment cover, thins from $\sim 33 \mathrm{~km}$ at the most continental 650 part, to $\sim 10 \mathrm{~km}$ through the $\mathrm{COB}$ and the change in the velocity of the lower crust may therefore be 651 interpreted as a density compensation to effect of boudinage process and/or as volcanic intrusions. 


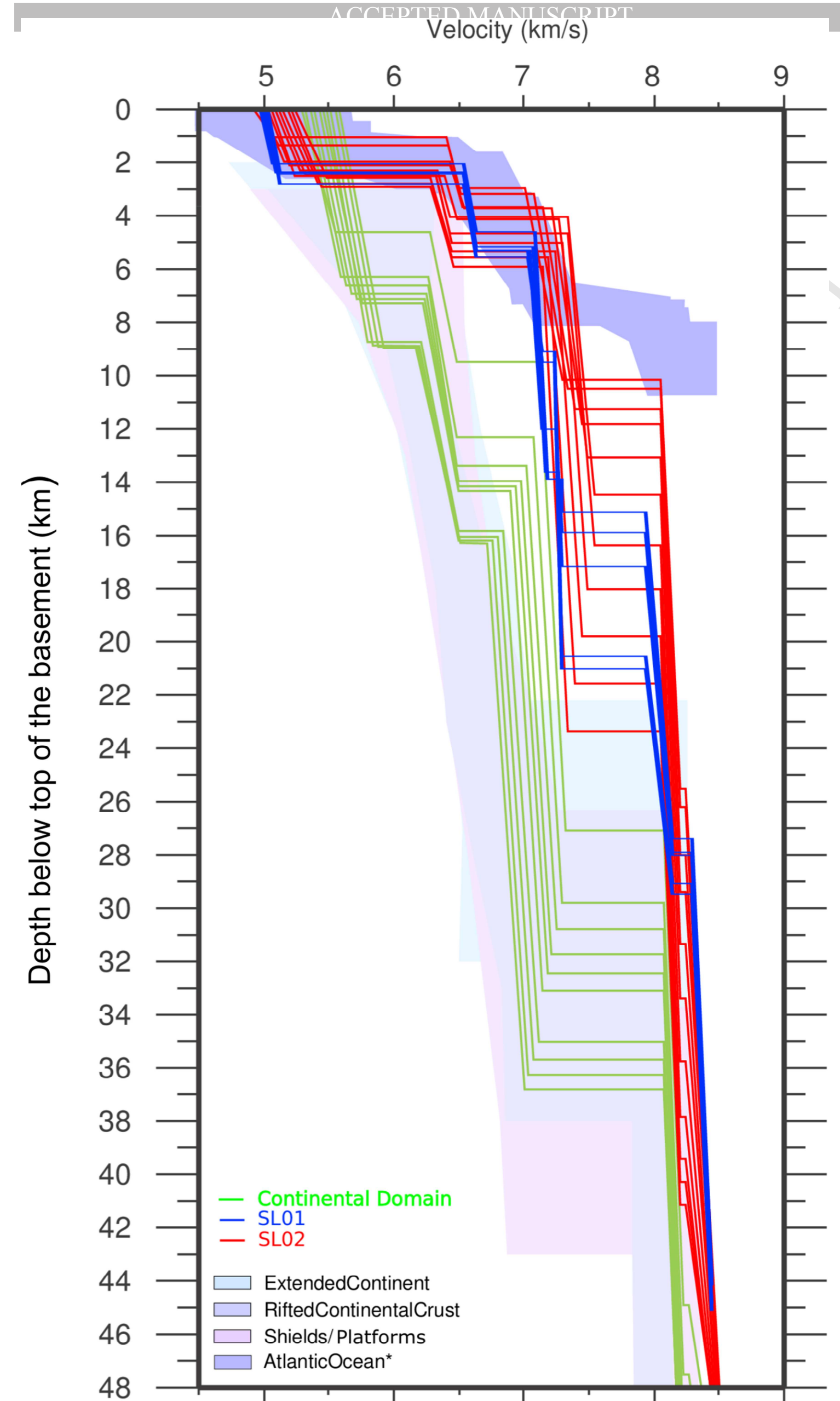


Figure 17: Compilation of $1 D$ velocity-depth profiles extracted below the top of the basement $(\mathrm{Vz})$ in the Unthinned Continental Domain (green lines) and the Necking Zone (red and blue lines). The blue shaded area bounds a compilation of velocity profiles for typical Atlantic oceanic crust (White et al., 1992), and light blue areas correspond to averaged velocity profiles for continental crust (Christensen and Mooney, 1995).

Figure 17 shows that the transition between the unthinned continental crust and the thinned domain preserves the configuration and the velocities of the crustal layers with strong velocity steps. The total crustal thickness has a sharp transition and the comparison of the $\mathrm{Vz}$ of the two profiles with the compilations for a typical continental crust (Christensen and Mooney, 1995) and for Atlantictype oceanic crust (White et al., 1992), shows that the crustal nature in the necking zone is closer to a typical continental crust than a typical oceanic crust (Figure 17). We propose that the necking seems therefore to be constituted by thinned continental crust, that presents a continuity of the velocity structure during the thinning process, without the presence of a transitional crust, and the main change to oceanic crust occurs outside the Necking Zone.

\section{Oceanic domain:}

668 The External Domains (25-210 km distance model on SL02 and 70-210 on SL01) show a thinner 669 crustal thickness and is interpreted as formed by oceanic crust. The sedimentary cover is also 670 thinner and reaches $3 \mathrm{~km}$. The top of the basement located at 6-8 $\mathrm{km}$ depth assumes a much more 671 regular topography. The crustal layers do not present any significant lateral velocity gradient 672 through the transition from continental to oceanic crust. Figures 15 and 18 show that, except under 673 the volcanic edifice, where the top of the basement follows the topography of the volcano, the 674 average depth of the oceanic basement varies between 6 to $8 \mathrm{~km}$ (Figure 8).

675 Due to the fact that this crust was formed during the Cretaceous Normal Superchron (CNS), a 676 magnetic quiet period, it presents a lack of reversal-related magnetic anomalies on crust of age 121 677 (Anomaly M0y) to 83.6 (Anomaly C34y) Ma old (Malinverno et al., 2012; Ogg, 2012; Granot et 678 al., 2014).

679 Nevertheless, the Vz profiles (Figure 18) along the profiles SL01 and SL02 show that the oceanic 680 basement and its layers fit almost perfectly the worldwide compilation for Atlantic-type oceanic 681 crust (White et al., 1992). The Moho has a range of depths below basement that varies from 612 $682 \mathrm{~km}$. It slightly rises from NW to SE in the proximal part of the oceanic domain (Figure 18), of the 683 closest to the transition with continental crust, and deepens under the volcanic edifice along SL02 684 profile. The rest of the oceanic crust thickness ranges from 8 to $6 \mathrm{~km}$ (Figure 18). Larger Moho 685 depths under the volcano can be justified due to the presence of the undercrustal layer that reflects 
686 isostasy compensation. Despite the thick crust in this area, crustal velocities go according with the 687 compilation of a typical oceanic crust (White et al., 1992). 


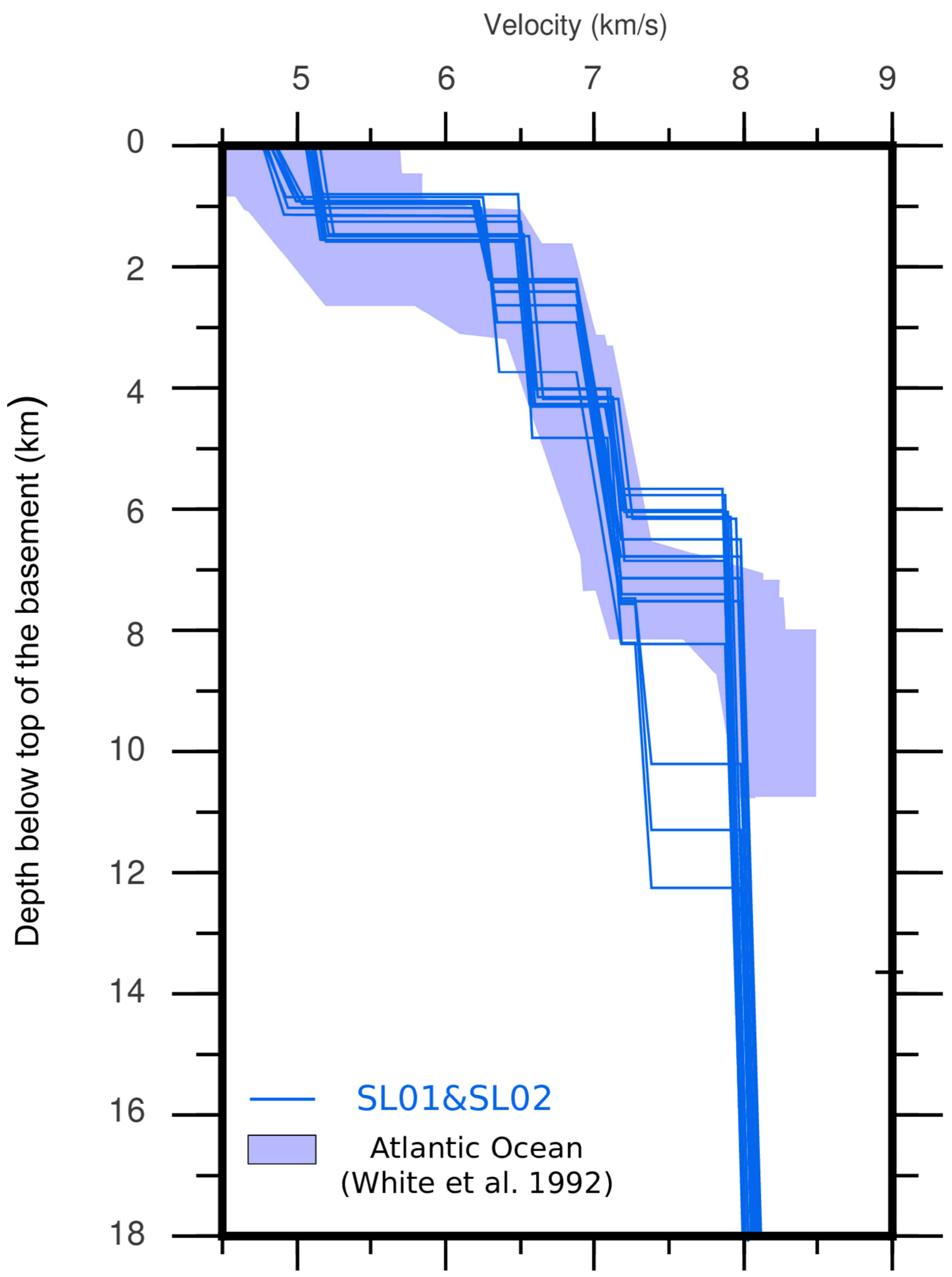


Figure: 18 Compilation of $1 D$ velocity-depth profiles extracted below the top of the basement (Vz) in the proposed Oceanic Crust. Colored lines mark individual Vz profiles at a $10 \mathrm{~km}$ interval of profiles SLO1 and SLO2. The blue shaded area bounds a compilation of velocity profiles for typical Atlantic oceanic crust (White et al., 1992).

The figure 8 shows a comparison between the data and the segmentation obtained in this work and a line-drawing of the ION-GXT seismic profiles. The wide-angle models go mostly in accord with the crustal structures interpreted from the ION-GXT lines, except for the Moho along SL01 which is modeled on average $2 \mathrm{~km}$ shallower with wide-angle data than the deepest reflector seen on the depth converted MCS line.

\section{Continental-Oceanic Boundary}

The transition between the continental and the oceanic domain is characterized in the MCS profiles (Figures 4 and 14) by a zone dominated by intracrustal reflectors. These reflectors in most part look like SDRs, but there is also some that are similar to LDRs. At this zone, the basement topography shows some mounds and little elevations. All these structures could be classified as a magmatic signature. Notwithstanding that, as Moulin et al. (2005) noticed already, these structures are not sufficient to characterize an archetype that could classify the margin of the SAB as a volcanic margin similar to the Greenland or Argentina Margins. Moreover, there is no evidence in the bibliography of volcanism before the first production of ocean crust. As described by Mohriak et al. (1998), these magmatic features are probably associated with extensional processes and oceanic crust inception, and they apparently post-date the rift phase lithospheric extension associated with the breakup of Gondwana in the Early Cretaceous, and were used by Mohriak et al. (1995, 1998) and Blaich et al. (2008) for their localization of the COB. Based on our wide-angle data analysis, we pointed the COB at $\sim 70 \mathrm{~km}$ from the coast, between the SL02OBS13 and SL02OBS12 along the SL02 profile just seaward of the slight velocity increase in the lower crust, and $\sim 100 \mathrm{~km}$ from the coast, between the SL01OBS05 and the SL01OBS06, along the SL01 profile just seaward of the intra-crustal velocity body, a little further seaward than the COB pointed by these authors.

\section{Conclusions}

The P-wave modelling of the SL01 and SL02 profiles reveals the deep crustal structure of the SAB passive margin off NE Brazil. From these models, we conclude that: 
The SAB margin is segmented parallel to the NE-SW coastline and the hinge line of the platform into a Continental Domain, a Necking Zone and an Oceanic Crust Domains without transitional domain.

- The oceanic crust is therefore rapidly reached, less than $100 \mathrm{~km}$ from the coast; its limit is parallel to the coast all along this segment. The COB is therefore situated a little further seaward than pointed out by Mohriak et al. $(1995,1998)$ and Blaich et al. (2008).

- These results show the huge segmentation in the offshore deep structures of the NE Brazilian margins since as opposed to this study a wide transitional domain of exhumed lower continental crust is imaged $350 \mathrm{~km}$ southwards in the Jequitinhonha margin (Loureiro et al., 2018).

- $\quad$ Onshore, LSS data along SL02 profile allow the characterization of the unthinned continental crust. It is $\sim 30-35 \mathrm{~km}$ thick, divided into three layers with velocities between 5.0 and $7.2 \mathrm{~km} / \mathrm{s}$. The results confirm the general trend modelled by previous studies of Mohriak et al. (1995, 1998); Blaich et al. (2008).

- The Necking Zone presents a rather sharp crustal thinning on the north of the VazaBarris fault (SL02), where the Moho goes from $31 \mathrm{~km}$ to $18 \mathrm{~km}$ depth in less than $100 \mathrm{~km}$, and the first thinning corresponds to the vanishing of the upper crust, that thins from $10 \mathrm{~km}$, at the continental domain, to less than $2 \mathrm{~km}$ through the COB, and keeps this thickness seawards. The Moho rises from a depth of $33 \mathrm{~km}$ at the limit with Continental Domain to a depth of $16 \mathrm{~km}$ through the COB. The lateral velocity variation happens only in the lower crust where it goes from 7.0 to $7.3 \mathrm{~km} / \mathrm{s}$ at the top and from 7.25 to $7.5 \mathrm{~km} / \mathrm{s}$ at the base. This wide-angle model shows a Moho located slightly $(2 \mathrm{~km})$ shallower than the one found by Mohriak et al. (1998) and confirms the gravity model of Blaich et al. (2008).

- $\quad$ Further SE, a $9 \mathrm{~km}$ thick typical oceanic crust is present, with a thin upper layer (1$1.5 \mathrm{~km}$ ) that presents velocities varying from 5.0 to $5.20 \mathrm{~km} / \mathrm{s}$, a $2.5 \mathrm{~km}$ thick middle layer with velocities of $6.5-6.6 \mathrm{~km} / \mathrm{s}$, and a thicker lower layer with $3-4 \mathrm{~km}$ thick and 6.9 to $7.1 \mathrm{~km} / \mathrm{s}$. The transition between the necking zone and this domain is characterized by a zone dominated by intracrustal reflectors, which could reflect a magmatic signature, notwithstanding that, as Moulin et al. (2005) noticed already, these structures are not sufficient to characterize an archetype that could classify the margin of the SAB as a volcanic margin. As described by Mohriak et al. (1998), these magmatic features are associated with extensional processes and oceanic crust inception, and they apparently post-date the rift phase lithospheric extension associated with the breakup of Gondwana in the Early Cretaceous. 
This oceanic crust is affected on profile SL02 by a volcanic edifice with $40 \mathrm{~km}$

754 extension where the basement rises almost $4 \mathrm{~km}$. The Bahia Seamounts chain has U/Pb ages from 75575 to $84 \mathrm{Ma}$ and is supposed to be related to a post-rift hotspot localized near the Middle Atlantic Ridge (MAR) (Skolotonev, 2012). Below this domain, there is a sub-crustal layer, very well constrained by the OBS and gravity data, with $\sim 5 \mathrm{~km}$ thick and $7.3 \mathrm{~km} / \mathrm{s}$ velocity. This layer is probably related to a magmatic underplating process where basaltic magmas are frequently trapped at or near the Moho, or within the crust, or in complex crust-mantle transition zones (Cox,1993).

- The undulated intracrustal reflectors, with an anticlinal shape, in the base of the lower crust of the necking zone in SL01 profile, added to the rise in the seismic velocity are a good evidence that the rift caused a lithospheric boudinage. This zone of boudinage is near of and is probably affected by the Vaza-Barris Transfer Zone. A similar feature is observed further in the south, at the Jequitinhonha Basin (Loureiro et al., 2018), where the crust is also affected by boudinage, near a zone of "necking zone wideness" transition. Buck et al. (1999) proposed that lithospheric boudinage is formed under local isostatic effect, sometimes called crustal buoyancy. Due to a possible heterogeneity, the crust was affected by a non-homogeneous thinning and extension, generating crustal boudinage. It can be explained by some transformations in the composition of the lower crust under the necking. On the other hand, this boudinage could be a consequence of magmatic intrusions formed during the rift process. However, the Pmp in the wideangle data, is clear and continuous, and do not seem to have been influenced by a volcanic intrusion.

- The SFB, which was in the margin of the Pernambuco Alagoas Domain, and was formed by thrust faulting of this domain over the São Francisco Craton during the Brasiliano orogeny, resulting in the collage of its crusts (Oliveira et al., 2010). The comparison between velocity models of the Pernambuco Alagoas Domain (Soares et al., 2010; Tavares et al., 2012; de Lima et al., 2015) and the São Francisco Domain (Soares et al., 2006 and Soares, personal communication), shows that the crust in the SFB is much more similar to the Pernambuco Alagoas Domain than to the São Francisco Craton. This could mean that the São Francisco crust was subducted and consumed, and the crust of the Pernambuco-Alagoas predominated in the Brasiliano orogenic event as it was proposed by Oliveira et al. (2010).

\section{Contributions}

784 The SALSA Project was led by D. Aslanian and M. Moulin, from Ifremer, and A. Viana and J. A. 785 Cupertino, from Petrobras. Modeling of the SALSA profile was done by M. Evain, A. Afilhado, F. 
Gallais, A. Loureiro, F. Schnurle and F. Klingelhoefer. On-land operation was conducted by J. Soares, R. Fuck, M. Vinicius de Lima, from the University of Brasilia (UnB) L. Matias, and C. Corela from the Instituto Dom Luis (IDL) of the University of Lisbon. Processing of the MCS seismic data was done by P. Schnurle. This work has been conducted as part of a PhD project supported by the Conselho Nacional de Desenvolvimento Científico e Tecnológico (CNPQ) from Brazil.

\section{Acknowledgments}

794

The data set collected during the SALSA experiment is protected under a partnership between IFREMER and Petrobras. Any request has to be addressed to Daniel Aslanian (aslanian@ifremer.fr) and Adriano Viana (aviana@petrobras.com.br). The authors wish to thank the captain, crew, and MCS technical team of the French R/V L'Atalante. Many thanks also to the OBS and land station technical teams who made this experiment possible. The GMT [Wessel and Smith, 1998], Seismic Unix software package [Stockwell, 1999], GEOCLUSTER software (CGG-Veritas), and RAYINVR software (Zelt and Smith, 1992; Zelt et al., 1999) were used in the preparation of this paper. The Salsa Team is composed by: Morvan, L. ${ }^{1}$; Mazé, J.P. ${ }^{1}$; Pierre, D. ${ }^{1}$; Roudaut-Pitel, M. ${ }^{\mathbf{1}}$; Rio, I. ${ }^{3}$, Alves, D..; Barros Junior, P. ; Biari, Y.1; Corela, C..; Crozon, J..; Duarte, J.L. ${ }^{3}$; Ducatel, C. ${ }^{1}$; Falcão, C. ${ }^{7}$; Fernagu, P. ${ }^{1}$; Le Piver, D. ${ }^{1}$; Mokeddem, Z. ${ }^{6}$; Pelleau, P. ${ }^{1}$; Rigoti, C. ${ }^{7}$; Roest, W.'; Roudaut, M. ${ }^{1}$.

We would like to thank two anonymous reviewers and the editor Dr. F. Audemard, who helped to improve significantly this manuscript.

\section{References}

Almeida F. F. M., Hasui Y., Brito Neves B.B. Fuck R.A. (1977). Províncias Estruturais Brasileiras. In: SBG-Núcleo Nordeste, Simpósio Geologia do Nordeste, 8, Campina Grande, Atas, Boletim 6, p. 363-391.

Austin, J. A., Jr., and Uchupi, E. (1982). Continental-oceanic crustal transition of Southwest Africa. Am. Assoc. Petrol. Geol. Bull., 66, 1328 \pm 1347

Bauer, K., Neben, S., Schreckenberger, B., Emmermann, R., Hinz, K., Fechner, N., Gohl, K., Schulze, A., Trumbull, R. B., Weber, K. (2000). Deep structure of the Namibia continental margin as derived from integrated geophysical studies. Journal of Geophysical Research: Solid Earth, 105(B11), 25829-25853.

Blaich, O.A., Tsikalas, F., Faleide, J.I. (2008). Northeastern Brazilian margin: regional tectonic evolution based on integrated analysis of seismic reflection and potential field data and modelling. Tectonophysics, 458: p.51-67.

Blaich, O.A., Faleide, J.I. Tsikalas, F. 2011. Crustal breakup and continent-ocean transition at South Atlantic conjugate margins. Journal of Geophysical Research, 116, B01402, doi:10.1029/2010JB007686. 
Black, R., and Girod, M. (1970). Late Paleozoic to Recent igneous activity in West Africa and its relationship to basement structure. African magmatism and tectonics, 1(8), 5-2.

Bonatti, E. (1996). Anomalous opening of the Equatorial Atlantic due to an equatorial mantle thermal minimum. Earth and Planetary Science Letters, 143: 147-170.

Buck, W. R., Lavier, L. L., Poliakov, A. N. (1999). How to make a rift wide. Philosophical Transactions-Royal Society of London Series a Mathematical Physical and Engineering Sciences, 671-689.

Cainelli, C. (1992). Sequence stratigraphy, canyons, and gravity mass flow deposits in the Piacabuçu Formation, Sergipe-Alagoas Basin, Brasil. PhD thesis, University of Texas at Austin, 233 p.

Cainelli, C., and Mohriak, W. U. (1998, November). Geology of Atlantic eastern Brazilian basins. In Brazilian Geology Part (Vol. 2, p. 1998).

Carvalho, M. J., (2005). Tectonic Evolution of the Marancó-Poço Redondo Domain: Records of the Cariris Velhos and Brasiliano Orogenesis in the Sergipano Belt, NE Brazil. Tese de doutorado. Universidade de Campinas.

Campos Neto, O., Lima, W. S., Cruz, F. G. (2007). Bacia de Sergipe-Alagoas. Boletim de Geociências da PETROBRAS, 15(2), 405-415.

Christensen, N. I., and Mooney, W. D. (1995). Seismic velocity structure and composition of the continental crust: A global view. Journal of Geophysical Research: Solid Earth, 100(B6), 97619788. doi:10.1029/95JB00259

Cohen, J. K. and Stockwell Jr., J. W. (2010). CWP/SU: Seismic Unix Release 42: a free package for seismic research and processing, Center for Wave Phenomena, Colorado School of Mines.

Cornacchia, M., and Dars, R. (1983). Un trait structural majeur du continent Africain; les lineaments centrafricains du Cameroun au Golfe d'Aden. Bulletin de la Société Géologique de France, 7(1), 101-109.

Conceição, J.C.J., Zalán, P.V., Wolff, S. 1988. Mecanismo, Evolução e Cronologia do Rift Sul-Atlântico, Boletim de Geociências da PETROBRAS, 2(4):255-265

Contrucci, I., Matias, L., Moulin, M., Géli, L., Klingelhofer, F., Nouzé, H., Aslanian D., Olivet J. L., Réhault J. P., Sibuet, J. C. (2004). Deep structure of the West African continental margin (Congo, Zaïre, Angola), between $5 \mathrm{~S}$ and $8 \mathrm{~S}$, from reflection/refraction seismics and gravity data. Geophysical Journal International, 158(2), 529-553.

Davison, I. and Santos, R.A., (1989). Tectonic evolution of the Sergipano Fold Belt, NE Brazil, during the Brasiliano Orogeny. Precamb. Res., 45. p. 319-342.

D'el-Rey Silva, L. J. H. (1999). Basin infilling in the southern-central part of the Sergipano Belt (NE Brazil) and implications for the evolution of Pan-African/Brasiliano cratons and Neoproterozoic sedimentary cover. South American Journal of Earth Sciences, 12: 453-470

Dumont, J. F. (1986). Identification par télédétection de l'accident de la Sanaga (Cameroun): Sa position dans le contexte des grands accidents d'Afrique Centrale et de la limite nord du craton Congolais. Géodynamique, 1(1), 13-19.

Eldholm, O., Thiede J., and Taylor E. (1989). Evolution of the Vøring volcanic margin, Proceedings of the Ocean Drilling Program - Scientific Results, 104, 1033-1065.

Feijó, F. J. (1994). Bacia de Sergipe-Alagoas. Boletim de Geociências da PETROBRAS, Rio de Janeiro, 8(1):149-161 
Gomes, P. O. (2005). Tectonismo, Vulcanismo, Sedimentação e Processos erosivos No Segmento Nordeste Da Margem Continental Brasileira. Phd thesis. Universidade Do Estado Do Rio De Janeiro Faculdade De Geologia.

Humphrey, F. L.; Allard, G. O. (1969). Geologia da área do domo de Itabaiana (SE) e sua relação com a geologia do geossinclinal de Propriá - Um elemento tectônico recem-conhecido no Escudo Brasileiro. (1969). Tradução de Munne, A. I., Barão, S. C. Rio de Janeiro, PETROBRAS/CENPES, 157 p. il.: mapa.

Klemperer, S. L., Hauge, T. A., Hauser, E. C., Oliver, J. E., Potter, C. J. (1986). The Moho in the northern Basin and Range province, Nevada, along the COCORP $40 \mathrm{~N}$ seismic-reflection transect. Geological Society of America Bulletin, 97(5), 603-618.

Korenaga, J., Holbrook, W. S., Kent, G. M., Kelemen, P. B., Detrick, R. S., Larsen, H. C., Dahl-Jensen, T. (2000). Crustal structure of the southeast Greenland margin from joint refraction and reflection seismic tomography. Journal of Geophysical Research: Solid Earth, 105(B9), 2159121614.

Lana, M. C. (1990) Bacia de Sergipe-Alagoas: Uma Hipótese de Evolução TectonoSedimentar. Origem e Evolução de Bacias Sedimentares - coordenadores Raja Gabaglia, G. P. e Milani, E. M - Petrobras/Serec/Censud, p.311-332.

de Lima, M. V. A., Berrocal, J., Soares, J. E., Fuck, R. A. (2015). Deep seismic refraction experiment in northeast Brazil: New constraints for Borborema province evolution. Journal of South American Earth Sciences, 58, 335-349.

Liu, Z., Bleistein, N. (1995). Migration velocity analysis: Theory and an iterative algorithm. Geophysics, 60(1), 142-153.

Ludwig W.J., Nafe J.E. Drake L.E. (1970). Seismic refraction. Maxwell, A.E. (Editor), The Sea. New concepts of sea floor evolution. Wiley-Interscience, New York, 4(I): 53-84.

Lutter, W. J., Nowack, R. (1990). Inversion for crustal structure using reflections from the PASSCAL Ouachita experiment. Journal of Geophysical Research: Solid Earth, 95(B4), 46334646.

Mohriak, W.U., Rabelo, J.H.L., Matos, R.D., Barros, M.C. (1995). Deep Seismic Reflection Profiling of Sedimentary Basins offshore Brazil: Geological Objectives and Preliminary Results in the Sergipe Basin. Journal of Geodynamics, 20:515-539

Mohriak, W.U., Bassetto, M. Vieira, I.S. (1998). Crustal Architecture and Tectonic Evolution of the Sergipe-Alagoas and Jacuípe Basins, Offshore Northeastern Brazil. Tectonophysics, 288:199-220.

Mohriak, W.U., Mello, M.R., Bassetto, M., Vieira, I.S., Koutsoukos, E.A.M. (2000). Crustal architecture, sedimentation, and petroleum systems in the Sergipe-Alagoas Basin, Northeastern Brazil. In: Mello, M.R., Katz, B.J. (eds.). Petroleum systems of South Atlantic margins, AAPG Memoir 73:273-300

Mohriak, W. U. (2003). Bacias sedimentares da margem continental Brasileira. Geologia, tectônica e recursos minerais do Brasil, 3, 87e165.

Moulin, M., D. Aslanian, J.-L. Olivet, I. Contrucci, L. Matias, L. Géli, F. Klingelhoefer, H. Nouzé, J.-P. Réhault, and P. Unternehr (2005). Geological constraints on the evolution of the Angolan margin based on reflection and refraction seismic data (ZaïAngo project). Geophysical Journal International, 162(3), 793-810.

Moulin, M., D. Aslanian, and P. Unternehr (2010), (2010). A new starting point for the South and Equatorial Atlantic Ocean. Earth-Science Reviews, 98(1-2), 1-37. 
Oliveira, D.C., Windley, B.F., Araújo, D.B. (2010). The Neoproterozoic Sergipano orogenic belt, NE Brazil: A complete plate tectonic cycle in western Gondwana. Precambrian Research 181, 64-84.

Oliveira, R. G. D. (2008). Arcabouço geofísico, isostasia e causas do magmatismo cenozóico da Província Borborema e de sua margem continental (Nordeste do Brasil).

Pavlis, N. K., Holmes, S. A., Kenyon, S. C., Factor, J. K. (2012). The development and evaluation of the Earth Gravitational Model 2008 (EGM2008). Journal of Geophysical Research: Solid Earth, 117(B4).

Sandwell, D. T., Müller, R. D., Smith, W. H., Garcia, E., Francis, R. (2014). New global marine gravity model from CryoSat-2 and Jason-1 reveals buried tectonic structure. Science, 346(6205), 65-67.

Sandwell, D., Smith, W. (1997). Marine gravity anomaly from GEOSAT and ERS-1 satellite altimetry. Journal of Geophysical Research, 102:10.039-10.054.

Santos, E. D., Silva Filho, M. A. (1975). Ensaio interpretativo sobre as evolução da Geossinclinal de Propriá, Nordeste do Brasil. Revista Mineração e Metalurgia, 367, 3-22.

Schaller, H. (1970). Revisão estratigráfica da bacia Sergipe-Alagoas. Boletim Técnico da Petrobrás. 12 (1): 21-86

Skolotnev S. G., Bylinskaya M. E, Golovina L. A., and Ipat'eva I. S. (2012). The Origin of Bahia Seamounts (Brazil Basin, South Atlantic) in Connection to New Data on Their Age. Doklady Earth Sciences, 2012, Vol. 443, Part 2, pp. 444-450. ISSN 1028_334X.

Silva Filho, M. A., (1998). Arco vulcânico Canindé-Marancó e a Faixa Sul-Alagoana: sequências orogênicas Mesoproterozóicas. In: XL Congresso Brasileiro de Geologia, Belo horizonte, SBG. p. 16.

Soares J.E.P., Berrocal J., Fuck R.A., Mooney W.D. Ventura D.B.R. (2006). Seismic characteristics of central Brazil crust and upper mantle: A deep seismic refraction study. Journal of Geophysical Research, 111: 1-31.

Soares, J. E. P., de Lima, M. V., Fuck, R. A., Berrocal, J. (2010). Características sísmicas da litosfera da Província Borborema: Resultados parciais do experimento de refração sísmica profunda. In IV Simpósio Brasileiro de Geofísica.

Stockwell, J. W., Jr. (1999), The CWP/SU: Seismic Un x package, Comput. Geosci., 25(4), 415-419, doi:10.1016/S0098-3004(98)00145-9.

Szatmari, P. (1998). Tectonic habitat of petroleum along the South Atlantic margins. In Am. Assoc. Petrol. Geol. International Conference Extended Abstracts Volume, Rio de Janeiro, Brazil, pp. $362 \pm 363$.

Szatmari, P., Milani, E.J. (1999). Microplate rotation in northeast Brazil during South Atlantic rifting: analogies with the Sinai microplate. Geology, 27(12):1115-1118

Tard F., Masse P., Walgenwitz F., Gruneisen P., The volcanic passive margin in the vicinity of Aden, Yemen, Bulletin des centres de recherche et d'exploration-production Elf-Aquitaine 15 (1991) 1-9

Tavares, E. J., Soares, J. E. P., Fuck, R. A., De Lima, M. V. A. (2012). Modelagem de onda P e razăo Vp/Vs da crosta sob a linha de refraçăo sísmica profunda NW-SE da Província Borborema. In V Simpósio Brasileiro de Geofísica.

White, R. S., McKenzie, D. and O'Nions, R. K. (1992). Oceanic crustal thickness from seismic measurements and rare earth element inversions. Journal of Geophysical Research: Solid Earth, 97(B13), 19683-19715. doi:10.1029/92JB01749. 
